\title{
Quality characterization of wheat, maize and sorghum steamed breads from Lesotho
}

\author{
Pulane Nkhabutlane $^{a}$, Gerrie E. du Rand ${ }^{a}$ and Henriëtte L. de Kock ${ }^{b}$ \\ ${ }^{a}$ Department of Consumer Science, University of Pretoria Private Bag X20, Hatfield, 0028 South \\ Africa
}

${ }^{\mathrm{b}}$ Department of Food Science, University of Pretoria Private Bag X20, Hatfield, 0028 South Africa

${ }^{*}$ Corresponding author: H. L. de Kock riette.dekock@up.ac.za

\begin{abstract}
BACKGROUND: In Lesotho, traditional bread covers different types of dumplings prepared with cereal flour, water, salt and sourdough. This study characterized eight steamed breads prepared from wheat, maize and sorghum. Breads were prepared from both commercial and self-milled flours according to the procedures followed in rural and urban areas of Lesotho. Descriptive sensory evaluation was conducted to profile sensory properties of the breads. Characterization of flour particle sizes, sourdough properties, colour, volume and texture of the bread were also obtained.
\end{abstract}

RESULTS: The type of cereal and milling properties of the flour used had substantial effects on the physical and sensory properties of the bread. Steamed wheat breads had greater volume, softer crumb and more bland flavour compared to sorghum and maize breads. Both sorghum and maize steamed breads prepared according to traditional Basotho procedures were characterised by low loaf volume, denser crumb, more complex and strong flavours and aroma notably sour, musty, malty, dairy sour and fermented aroma. The texture of the non-wheat bread types was heavy, chewy, dry, fibrous, more brittle and needed a higher compression force to deform. 
CONCLUSIONS: This study provided insight on the sensory properties of steamed bread as prepared in Lesotho. Further research is needed to optimise sensory properties of the nonwheat steamed breads by controlling flour particle size, compositing non-wheat flours with different levels of wheat flour, addition of protein sources and gums, altering the amount of water, improving on the pre-gelatinization process and optimising the steaming method of cooking bread.

Keywords: wheat, maize, sorghum, bread, Lesotho, sensory.

\section{INTRODUCTION}

Breads from three cereals [wheat (Triticum aestivum), maize (Zea Mays) and sorghum (Sorghum bicolor)] are staple foods in Lesotho. Basotho (the people of Lesotho) perceive bread as the most important and tastiest food compared to other cereal products ${ }^{1}$. Steamed wheat bread (Leqebekoane) is generally more preferred than maize (Monepola oa poone ea thooko) and sorghum bread (Ntsoanatsike). However, poor climatic conditions in Lesotho limits production of wheat, therefore about $75 \%$ of its wheat flour is imported ${ }^{2}$. As a consequence, consumption of wheat bread has become very expensive and is not afforded by poor families ${ }^{3}$. Maize yields much higher than wheat $^{3}$, and the use of non-wheat cereals (maize and sorghum) in bread making as traditionally practiced by Basotho could significantly reduce bread costs.

Basotho bread basically consists of flour, sourdough, salt and water. Commercial instant yeast and sugar are sometimes included in the urban areas. The main processing steps include flour milling, kneading the dough, fermentation and cooking. Pre-gelatinization of starch is always applied during preparation of maize and sorghum breads and the fermented dough is mostly cooked using the steaming method. In Lesotho, preparation and consumption of such traditional steamed bread still occurs mainly in the household. Apart from its daily use, bread in Lesotho is also served as a delicacy on special occasions and 
feasts. Commercial sale of traditional bread is limited to informal street vendors in urban areas.

Various studies in China ${ }^{4-8}$. South Africa ${ }^{9-11}$ and Ghana ${ }^{12,13}$ have characterized steamed breads. The general culinary practices (type of ingredients, processing techniques and flavourings) are important determinants of the physical and sensory characteristics of breads $^{14}$. These attributes can be described and quantified using sensory and physical instrumental analyses ${ }^{15}$. To our knowledge no scientific study to characterise traditional Basotho steamed bread has been published. The main objective of the present study was to profile and characterize steamed breads prepared according to the culinary practices of the Basotho.

\section{MATERIALS AND METHODS}

\section{Standardization of recipes}

A prior qualitative investigation in rural and urban regions of Lesotho was conducted to obtain information on the culinary practices for Basotho steamed breads (not reported here). The regional variations were considered during standardization of bread recipes. For each cereal, bread was prepared from both freshly milled whole grains and commercial flours. Variation of ingredients in the breads was meant to represent both the traditional and the modern ways of preparing bread in Lesotho (Table 1).

Flours. Wheat, white maize, white and red non-tannin (verified according to the method described by Taylor, 2001) ${ }^{16}$ sorghum whole grains were obtained from local farmers in Lesotho. The grains were thoroughly cleaned by winnowing, sieving and sorting. The grains were stone ground using an "Original Osttiroler Getreidemuhlen" (A-9991 Dolsach/Stribach 55 Austria). The mill was adjusted to $5 \mathrm{~mm}$ for whole grain coarse flours (wheat, maize and sorghum) and to $3 \mathrm{~mm}$ for fine whole grain wheat flour. The flour particle sizes were chosen to resemble the coarseness of flour manually ground using grinding stones in Lesotho. The 
Table 1 Standardized recipe formulations used to prepare 8 steamed breads from whole grain flours and commercial flours Wheat Breads

Sorghum Breads

\begin{tabular}{|c|c|c|c|c|c|c|c|c|}
\hline \multirow{2}{*}{ Ingredients } & & & \\
\hline & CWWheat & FWWheat & ComWheat & WRSorg & ComRSorg & WWhSorg & WWhMaize & ComWhMaize \\
\hline $\begin{array}{l}\text { Flour }(\mathrm{g}) \\
\text { Coarsely milled whole wheat (CWWheat) }\end{array}$ & 170 & & & & & & & \\
\hline Finely milled whole wheat (FWWheat) & & 170 & & & & & & \\
\hline $\begin{array}{l}\text { Commercial wheat (ComWheat) } \\
\text { Letlotlo Easy Bake flour ( Lesotho flour mills) }\end{array}$ & & & 170 & & & & & \\
\hline Whole grain red sorghum (WRSorg) & & & & 170 & & & & \\
\hline $\begin{array}{l}\text { Commercial red sorghum (ComRSorg) } \\
\text { Monati Super Mabela- pure grain sorghum fine } \\
\text { meal [Nola Foods (Pty) Ltd South Africa], }\end{array}$ & & & & & 170 & & & \\
\hline Whole grain white sorghum (WWhSorg) & & & & & & 170 & & \\
\hline Whole grain white maize (WWhMaize) & & & & & & & 170 & \\
\hline $\begin{array}{l}\text { Commercial special white maize (ComWhMaize) } \\
\text { Impala special maize meal (Premier Foods, } \\
\text { Isando, South Africa) }\end{array}$ & & & & & & & & 170 \\
\hline $\begin{array}{l}\text { Water } \\
\text { Luke warm water }(\mathrm{g})\left(35^{\circ} \mathrm{C}\right) \\
\text { Boiling water }(\mathrm{g})\left(96^{\circ} \mathrm{C}\right)\end{array}$ & 110 & 110 & 110 & 140 & 140 & 140 & 140 & 140 \\
\hline $\begin{array}{ll}\text { Sourdough }(\mathrm{g}) & (1: 1 \mathrm{w} / \mathrm{w} \text { flour:tap water }) \\
\text { Instant yeast }(\mathrm{g}) & \\
\text { Salt }(\mathrm{g}) & \\
\text { Sugar }(\mathrm{g}) & \\
\text { Cooking oil }(\mathrm{g}) & \end{array}$ & $\begin{array}{l}60 \\
0.5 \\
3\end{array}$ & $\begin{array}{l}60 \\
0.5 \\
3\end{array}$ & $\begin{array}{l}60 \\
0.5 \\
3 \\
10\end{array}$ & $\begin{array}{l}60 \\
0.5 \\
2\end{array}$ & $\begin{array}{l}60 \\
0.5 \\
2 \\
15 \\
10\end{array}$ & $\begin{array}{l}60 \\
0.5 \\
2\end{array}$ & $\begin{array}{l}60 \\
0.5 \\
2\end{array}$ & $\begin{array}{l}60 \\
0.5 \\
2 \\
15 \\
10 \\
\end{array}$ \\
\hline Total weight $(\mathrm{g})$ & 343.5 & 343.5 & 353.5 & 372.5 & 397.5 & 372.5 & 372.5 & 397.5 \\
\hline
\end{tabular}


first $1 \mathrm{~kg}$ of flour was discarded before collecting flour to be used for bread making. Flours were kept in sealed containers at $5{ }^{\circ} \mathrm{C}$ for a week before use. Commercial maize and sorghum flours and commercial wheat flour were respectively bought at supermarkets in Pretoria, South Africa and Maseru, Lesotho.

Flour particle size. Flour particle size fractions were determined in triplicate following Kebakile et al. $(2008)^{17}$. The procedure involved sifting $20 \mathrm{~g}$ of flour for $3 \mathrm{~min}$ through (106, $250,500,1000 \& 1400 \mu \mathrm{m})$ Star screens test sieves.

Proximate analysis of flours. The moisture content of the flours was determined by oven drying method ${ }^{18}$, Method 44-15A. Protein content was measured by the Dumas combustion method $^{18}$, Method 46-30, using nitrogen conversion factors $\mathrm{N} \times 5.83$ for wheat and $\mathrm{N} \times 6.25$ for sorghum and maize flours. Crude fat was determined by a Soxhlet extraction method ${ }^{18}$, Method 30-25. Ash was determined using a muffle oven according to AACC International $(2000)^{18}$, Method 08-01. The carbohydrate content was determined by the difference by summing up the determined values of moisture, ash, protein, crude fat and deducting from the total weight of the food ${ }^{19}$.

Preparation of sourdough. Sourdoughs ( $3 \mathrm{~kg}$ batches) were prepared by mixing 1:1 w/w flour to tap water by hand to form smooth dough. The dough, in a plastic container with a lid, was incubated at $25{ }^{\circ} \mathrm{C}$ for $24 \mathrm{~h}$. The sourdoughs were kept in the refrigerator at and refreshed with 1:1 flour to tap water $(500 \mathrm{~g})$ once a week. Refreshed sourdough was left for $24 \mathrm{~h}$ before use.

Preparation of wheat breads. All ingredients were mixed using Kenwood Chef Excel Mixer - KM 210 model with dough hoo at speed for $\min$ he dough was in $\mathrm{u}$ a ted at for $3 \mathrm{~h}$. The leavened dough was then pressed down with hands to release air and allowed to ferment again for $2 \mathrm{~h}$. 
Preparation of maize and sorghum breads. A mixture of boiling water $(9$ and flour was stirred with a wooden spoon in a plastic container and allowed to cool before sourdough and other ingredients were added. Mixing was done with Kenwood dough hook at speed 3 for $5 \mathrm{~min}$. The dough was incubated for $8 \mathrm{~h}$ at 3

Breads were prepared and steamed in triplicate in an aluminium saucepan $(8 \mathrm{~L})$ with a tightly fitting lid as is done by urban consumers in Lesotho. The fermented dough was shaped into a ball and placed in a round, stainless steel bowl (80 mm height and $125 \mathrm{~mm}$ diameter) greased with sunflower oil. The bowl was then placed on a wire mesh that elevated the bread $60 \mathrm{~mm}$ above $2 \mathrm{~L}$ of boiling water. The bread was steamed for $90 \mathrm{~min}$. Cooked bread was cooled at room temperature for $30 \mathrm{~min}$, packaged in zip lock plastic bags and stored at $18 \mathrm{C}$ before further analyses.

Standard breads. Two commercial breads, 100\% plain Rye bread - Astoria bakery, South Africa and Sasko Premium whole wheat bread (Sasko bakeries, South Africa) were included as standards for the descriptive sensory testing.

Total titratable acidity (TTA) and pH of sourdough and bread dough. The TTA and pH were determined in triplicate from 0-2 days for sourdough and prior to baking for bread dough according to the method by Lönner et al. $(1986)^{20}$. For each sourdough batch and for each dough batch a $5 \mathrm{~g}$ sample was blended with $20 \mathrm{~mL}$ distilled water. The $\mathrm{pH}$ was measured using a Hanna Instruments Microprocessor pH 211 meter with a glass electrode. The suspensions were then titrated with $0.1 \mathrm{~N} \mathrm{NaOH}$ to $\mathrm{pH}$ 6.3. The TTA was expressed as $\%$ lactic acid ${ }^{21}$. 
Physical properties of breads. The bread weights were recorded after $30 \mathrm{~min}$ of cooling. The fresh bread volumes were measured by the rapeseed displacement method ${ }^{22}$. Breads were placed in a graduated $(5 \mathrm{~L})$ glass cylinder. The rapeseeds were then run into the same container until it was full. The volume of seeds displaced by the loaf was recorded as the loaf volume. The specific volume $\left(\mathrm{cm}^{3} / \mathrm{g}\right)=\frac{\text { Loaf Volume }}{\text { Loaf Weight }}$ of bread was then calculated according to the AACC method $(2000)^{18}$.

Crumb texture. The crumb texture of breads previously frozen and thawed overnight at room temperature $\left(\begin{array}{ll}25 & \mathrm{C}\end{array}\right)$, was measured using AACC method 74-09.01 (2009) ${ }^{23}$. The breads were centre sliced ( $25 \mathrm{~mm}$ thick) using an electric knife. For standard breads, 2 slices of $12.5 \mathrm{~mm}$ each were stacked together. The texture was determined using an $\mathrm{EZ}-\mathrm{L}$ Shimadzu texture analyzer equipped with a $10 \mathrm{~mm}$ diameter perspex probe. The bread samples were positioned between the load cell and the plate of the machine. A $5000 \mathrm{~N}$ load cell was used for traditional breads and a $50 \mathrm{~N}$ load cell was used for commercial bread. The probe compressed the crumb to a $40 \%$ compression limit (10-mm compression depth) at 10 $\mathrm{mm} / \mathrm{min}$ speed. The analysis was performed at 3 positions (left, centre and right) of bread slices in triplicate.

Bread appearance. Three $25 \mathrm{~mm}$ thick centre slices from breads illuminated with 2 Elinchrom flashes fitted with umbrellas and placed against a neutral white paper background, were photographed (Nikon D700 digital camera with a $105 \mathrm{~mm}$ macro lens) from a $0.5 \mathrm{~m}$ distance. 
Colour measurements. The skin and crumb colour of breads, thawed overnight at C were measured in triplicate with a Konica Minolta Chroma Meter CR - 400 (Konica Minolta Sensing, INC, NARICH CC). The $L^{*} a^{*} b^{*}$ values were used to calculate chroma $\sqrt{a^{2}+b^{2}}$ and hue angle tan-1(b/a).

Descriptive sensory evaluation. Sensory characterization of traditional Basotho bread was performed by a trained panel of 10 assessors using the generic descriptive method ${ }^{24}$. The panel participated in seven $2 \mathrm{~h}$ training sessions and generated 36 attributes and scales describing differences among the breads (Table 3). The breads were thawed overnight at room temperature. Samples were sliced $(15 \mathrm{~mm})$ using an electric knife and three centre slices were used. The slices were cut into rectangular shapes $(40 \mathrm{~mm} \times 20 \mathrm{~mm})$ of approximately $20 \mathrm{~g}$ each, placed in an individual transparent polyethylene zip-lock bag (100 x $110 \mathrm{~mm}$ ) labelled with a 3-digit random code. All ten bread samples were presented simultaneously in a randomized order to the panellists. Breads were evaluated in triplicate in three sessions of $1 \mathrm{~h}$ each on three consecutive days. Filtered water was used for palate cleaning. Evaluation was carried out in the sensory laboratory of the University of Pretoria. Compusense ${ }^{\circledR}$ five, release 4.6 (Compusense Inc., Guelph, ON, Canada) was used to collect responses. 
Statistical analysis. One way analysis of variance (ANOVA) was performed to determine the effect of bread type on dependent variables $(\mathrm{pH}$, TTA, texture, colour and sensory attributes) or flour type on proximate composition. All means were compared using the least significant difference (LSD) test at $p \leq \quad$ Two-way ANOVA was used to determine the effect of bread type and slice position on crumb firmness of breads. The mean scores of significant sensory attributes were subjected to principal component analysis (PCA) using the correlation matrix with bread types in columns and attributes in rows. The data processing was performed using SAS ${ }^{\circledR}$ version 9.3 (SAS Institute INC, SAS campus Drive, Cary, NC 27513) under Microsoft Windows XP (SP3) on a desk top computer.

\section{RESULTS}

Flour particle size distribution. The flour particle size distribution of milled grains and commercial flours is presented in Figure 1. ComWheat flour was the finest with $57 \%$ of the flour passing through the smallest (106) $\mu \mathrm{m}$ sieve. ComWheat flour was much finer than the self-milled wheat grains. The particle size distributions of the three sorghum flours were similar. ComRSorg had a smaller percentage (10\%) of fine particles compared to WRSorg $(18 \%)$ and WWhSorg (17\%), but WWhSorg comprised of more $(85 \%)$ particles at $500 \mu \mathrm{m}$ than WRSorg $(77 \%)$ and ComRSorg $(79 \%)$. The main difference between the two maize flours were an even proportion of both very small (8\%) and very large (1000- $1400 \mu \mathrm{m})$ particles in the self-milled flour compared to mostly evenly sized particles of 106-500 $\mu \mathrm{m}$ in the ComMaize flour. ComMaize meal had the lowest $\%$ of really small particles $(<106 \mu \mathrm{m})$ but the largest proportion of particles $250-500 \mu \mathrm{m}$. CWWheat and WWhMaize flours had the largest percentage of coarse particles $1000-1400 \mu \mathrm{m}$ (about 10\%). No particles $>1000$ $\mu \mathrm{m}$ were recorded for the sorghum flours.

Proximate composition of flours. The proximate composition of the flours used for the steam breads is presented in Table 2. The results for wheat and sorghum flours and for maize were comparable to values recorded previously ${ }^{25,26}$. 


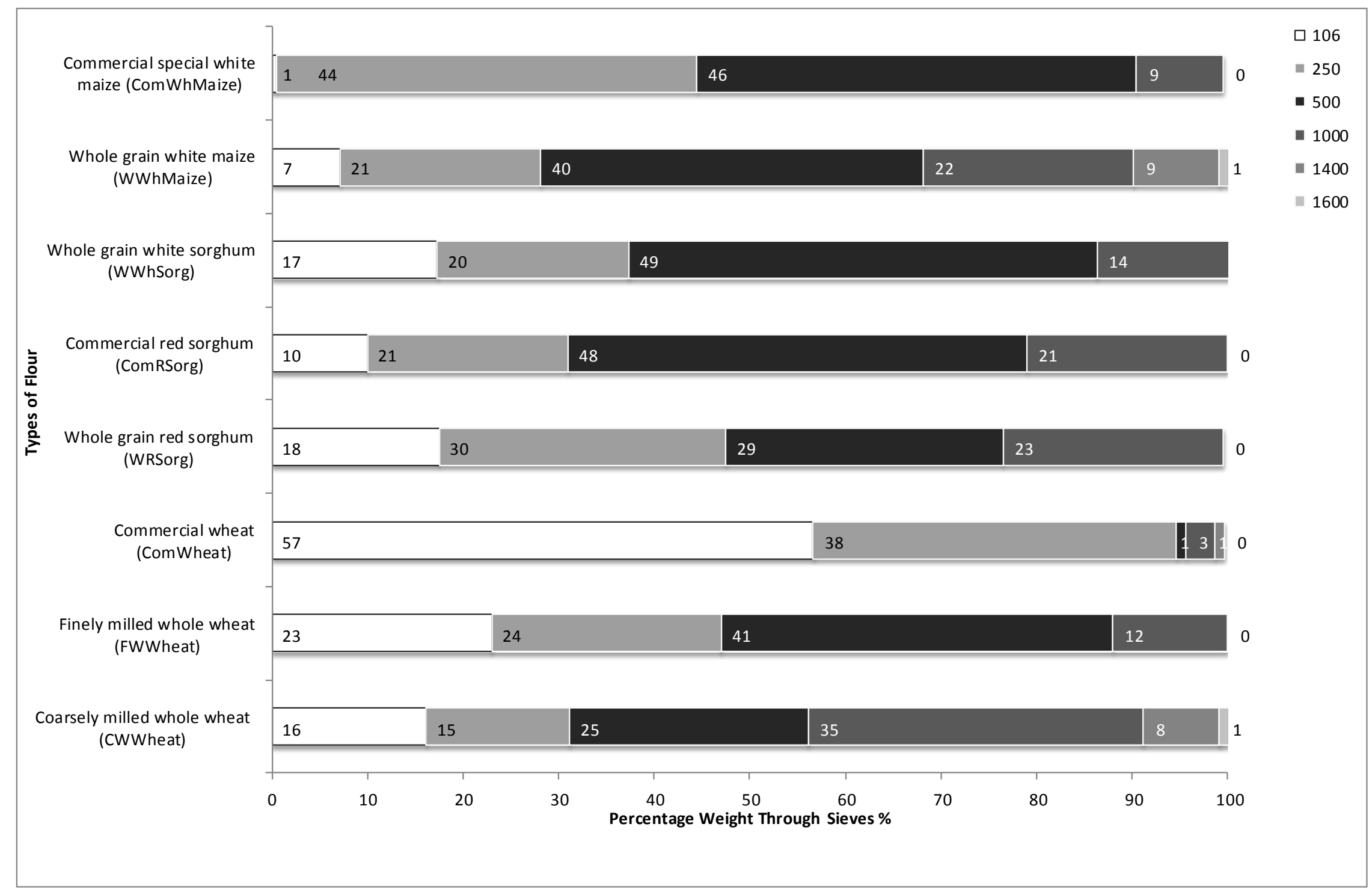

Figure 1 Particle size distribution (\% particles that pass through various size sieves) of whole grain and commercial wheat, maize and sorghum flour 
Table 2 Proximate composition (\%) of whole grain and commercial flours

\begin{tabular}{|c|c|c|c|c|c|}
\hline Flours & $\begin{array}{l}\text { Moisture } \\
\text { (\%) }\end{array}$ & $\begin{array}{l}\text { Protein } \\
(\% d w b)\end{array}$ & $\begin{array}{l}\text { Crude Fat } \\
\text { (\% dwb) }\end{array}$ & $\begin{array}{l}\text { Ash } \\
\text { (\% dwb) }\end{array}$ & $\begin{array}{l}\text { Carbohydrates } \\
\text { (by difference) } \\
\text { (\% dwb) }\end{array}$ \\
\hline Coarsely milled whole wheat (CWWheat) & $11.20^{b} \pm 0.06$ & $10.48^{\mathrm{e}} \pm 0.08$ & $1.60^{\mathrm{a}} \pm 0.06$ & $1.71^{\mathrm{e}} \pm 0.02$ & $86.21^{d} \pm 0.04$ \\
\hline Finely milled whole wheat (FWWheat) & $11.80^{d} \pm 0.02$ & $13.05^{f} \pm 0.07$ & $1.33^{\mathrm{a}} \pm 0.05$ & $1.69^{\mathrm{e}} \pm 0.04$ & $83.93^{\mathrm{a}} \pm 0.09$ \\
\hline Commercial wheat (ComWheat) & $11.63^{c} \pm 0.09$ & $13.34^{\mathrm{g}} \pm 0.06$ & $1.61^{a} \pm 0.08$ & $1.01^{b} \pm 0.00$ & $84.03^{a} \pm 0.14$ \\
\hline Whole grain red sorghum (WRSorg) & $12.72^{f} \pm 0.11$ & $8.20^{b} \pm 0.01$ & $2.77^{b} \pm 0.14$ & $1.55^{d} \pm 0.04$ & $87.48^{\mathrm{e}} \pm 0.19$ \\
\hline Commercial red sorghum (ComRSorg) & $11.95^{\mathrm{e}} \pm 0.03$ & $9.69^{d} \pm 0.09$ & $2.51^{b} \pm 0.06$ & $1.30^{c} \pm 0.04$ & $86.50^{d} \pm 0.11$ \\
\hline Whole grain white sorghum (WWhSorg) & $11.09^{b} \pm 0.09$ & $9.69^{d} \pm 0.01$ & $3.75^{c} \pm 0.10$ & $1.91^{f} \pm 0.00$ & $84.64^{b} \pm 0.10$ \\
\hline Whole grain white maize (WWhMaize) & $11.86^{\mathrm{de}} \pm 0.01$ & $9.43^{c} \pm 0.02$ & $3.76^{c} \pm 0.39$ & $1.73^{\mathrm{e}} \pm 0.03$ & $85.07^{c} \pm 0.40$ \\
\hline Commercial special white maize (ComWhMaize) & $10.87^{\mathrm{a}} \pm 0.01$ & $7.86^{\mathrm{a}} \pm 0.02$ & $3.75^{c} \pm 0.05$ & $0.94^{\mathrm{a}} \pm 0.04$ & $87.45^{\mathrm{e}} \pm 0.07$ \\
\hline
\end{tabular}

Values are means \pm standard deviations. ${ }^{\text {abcdef }}$ Values in the same column with different letters are significantly different at $p \leq \% d w b$ - Percentage dry weight basis. 
Table 3 Description lexicon used by the sensory panel for wheat, sorghum and maize steamed breads

\begin{tabular}{|c|c|c|c|}
\hline \multirow{2}{*}{\multicolumn{2}{|c|}{$\begin{array}{cc}\text { Attributes } & \text { Definition } \\
\text { Aroma/smell (scale: } 0=\text { not intense; } 100=\text { very intense) }\end{array}$}} & \multicolumn{2}{|c|}{ References (and scale } \\
\hline & & \\
\hline Overall bread & $\begin{array}{l}\text { Intensity of the overall aroma of the } \\
\text { bread }\end{array}$ & & \\
\hline Fermented & $\begin{array}{l}\text { Intensity of aroma associated with } \\
\text { fermented bread }\end{array}$ & \multicolumn{2}{|c|}{ Wheat dough fermented for $8 \mathrm{~h}$ at $30^{\circ} \mathrm{C}=100$} \\
\hline Yeasty & $\begin{array}{l}\text { Intensity of aroma characteristic of } \\
\text { yeast used as a leavening agent }\end{array}$ & \multicolumn{2}{|c|}{$\begin{array}{l}\text { Mixture of commercial instant yeast and water } \\
\text { in a ratio of } 1: 1=100\end{array}$} \\
\hline Malty & $\begin{array}{l}\text { Intensity of aroma typical of African } \\
\text { traditional beer with sour overtones }\end{array}$ & \multicolumn{2}{|c|}{ Sorghum beer $($ Chibuku $)=100$} \\
\hline Musty /earthy & Intensity of aroma typical of wet grains & \multicolumn{2}{|c|}{ Sorghum soaked in water for $24 \mathrm{~h}=100$} \\
\hline Cereals/grain & $\begin{array}{l}\text { Intensity of aroma typical of } \\
\text { cereal/grains (sorghum, maize, wheat) }\end{array}$ & \multicolumn{2}{|l|}{ Whole wheat grains $=50$} \\
\hline Herbal & $\begin{array}{l}\text { Intensity of aroma characteristic of } \\
\text { herbal tea }\end{array}$ & \multicolumn{2}{|c|}{$\begin{array}{l}\text { Black forest tea bag soaked in } 250 \mathrm{ml} \text { boiling } \\
\text { water }=100\end{array}$} \\
\hline Cooked sorghum & $\begin{array}{l}\text { Intensity of aroma typical of cooked } \\
\text { sorghum flour }\end{array}$ & \multicolumn{2}{|c|}{ Thick sorghum porridge ( $25 \%$ solids $)=100$} \\
\hline $\begin{array}{l}\text { Freshly baked wheat } \\
\text { bread }\end{array}$ & $\begin{array}{l}\text { Intensity of aroma characteristic of } \\
\text { freshly baked wheat bread }\end{array}$ & \multicolumn{2}{|c|}{$\begin{array}{l}\text { Traditional white bread (Sasko) } \\
=100\end{array}$} \\
\hline Dairy sour & $\begin{array}{l}\text { Intensity of aroma characteristic of } \\
\text { fermented sour dairy products such as } \\
\text { butter milk and cream cheese }\end{array}$ & \multicolumn{2}{|c|}{ Philadelphia Cream cheese $=100$} \\
\hline \multicolumn{4}{|c|}{ Texture attributes of breadcrumb evaluated by finger feel } \\
\hline Dryness & $\begin{array}{l}\text { Degree of dryness of bread crumb by } \\
\text { feeling with fingers }\end{array}$ & $\begin{array}{l}\text { Traditional white } \\
\text { bread (Sasko) }=50\end{array}$ & $\begin{array}{l}0=\text { Not dry } / \text { moist } \\
100=\text { Very dry }\end{array}$ \\
\hline Crumbliness & $\begin{array}{l}\text { Degree to which bread particles are } \\
\text { loose when crumb is rubbed between } \\
\text { thumb and index fingers }\end{array}$ & $\begin{array}{l}\text { Traditional white } \\
\text { bread (Sasko) }=0\end{array}$ & $\begin{array}{l}0=\text { Not crumbly } \\
100=\text { Very crumbly }\end{array}$ \\
\hline Springiness & $\begin{array}{l}\text { Degree to which the crumb returns to } \\
\text { initial shape after moderate pressure by } \\
\text { compressing the sample between } \\
\text { thumb and index finger. }\end{array}$ & $\begin{array}{l}\text { Traditional white } \\
\text { bread (Sasko) }=100\end{array}$ & $\begin{array}{l}0=\text { Not springy } \\
100=\text { Very springy }\end{array}$ \\
\hline \multicolumn{4}{|c|}{ Texture Attributes by mouth feel } \\
\hline Firmness of first bite & Force required by molars to bite bread. & $\begin{array}{l}\text { Traditional white } \\
\text { bread (Sasko) }=50\end{array}$ & $\begin{array}{l}0=\text { Not firm } \\
100=\text { Very firm }\end{array}$ \\
\hline Roughness of crumb & $\begin{array}{l}\text { Degree of abrasiveness of bread } \\
\text { surface on lips. Presence of any } \\
\text { particles, lumps, bumps, etc. }\end{array}$ & $\begin{array}{l}\text { Traditional white } \\
\text { bread (Sasko) }=0\end{array}$ & $\begin{array}{l}0=\text { Not rough } \\
100=\text { Very rough }\end{array}$ \\
\hline Dryness & Degree of dryness while chewing & $\begin{array}{l}\text { Traditional white } \\
\text { bread (Sasko) }=50\end{array}$ & $\begin{array}{l}0=\text { Not dry } \\
100=\text { Very dry }\end{array}$ \\
\hline Cohesiveness & $\begin{array}{l}\text { Degree to which the bread holds } \\
\text { together or deforms while chewing }\end{array}$ & $\begin{array}{l}\text { Cooked thick maize } \\
\text { porridge }(35 \% \text { solids }) \\
=100\end{array}$ & $\begin{array}{l}0=\text { Not cohesive } \\
100=\text { Very cohesive }\end{array}$ \\
\hline Graininess/grittiness & $\begin{array}{l}\text { Degree to which bread contains small } \\
\text { grainy or gritty particles. }\end{array}$ & $\begin{array}{l}\text { Cooked coarsely } \\
\text { ground thick sorghum } \\
\text { porridge ( } 35 \% \text { solids) } \\
=100\end{array}$ & $\begin{array}{l}0=\text { Not grainy } \\
100=\text { Very grainy }\end{array}$ \\
\hline
\end{tabular}




\begin{tabular}{|c|c|c|c|}
\hline Heaviness & $\begin{array}{l}\text { Weight of product perceived when first } \\
\text { placed on tongue. }\end{array}$ & $\begin{array}{l}\text { Traditional white } \\
\text { bread (Sasko) }=50\end{array}$ & $\begin{array}{l}0=\text { Not heavy } \\
100=\text { Very heavy }\end{array}$ \\
\hline Firmness of crumb & $\begin{array}{l}\text { Degree to which bread deforms during } \\
\text { chewing in the mouth }\end{array}$ & $\begin{array}{l}\text { Traditional white } \\
\text { bread (Sasko) }=50\end{array}$ & $\begin{array}{l}0=\text { Not firm } \\
100=\text { Very firm }\end{array}$ \\
\hline Chewiness & $\begin{array}{l}\text { Number of chews required before bread } \\
\text { is ready for swallowing }\end{array}$ & $\begin{array}{l}\text { Traditional white } \\
\text { bread (Sasko) }=50\end{array}$ & $\begin{array}{l}0=\text { Few } \\
100=\text { Many }\end{array}$ \\
\hline Fibrousness & $\begin{array}{l}\text { The amount of fibres/bran present in } \\
\text { the bread }\end{array}$ & $\begin{array}{l}\text { Cooked coarsely } \\
\text { ground thick maize } \\
\text { porridge ( } 35 \% \text { solids) } \\
=100\end{array}$ & $\begin{array}{l}0=\text { Not fibrous } \\
100=\text { Very fibrous }\end{array}$ \\
\hline \multicolumn{4}{|c|}{ Flavour (scale: 0 = not intense; 100 = very intense) } \\
\hline Overall flavour & $\begin{array}{l}\text { Intensity of overall flavour of bread } \\
\text { crumb while chewing }\end{array}$ & & \\
\hline $\begin{array}{l}\text { Cooked whole wheat } \\
\text { flavour }\end{array}$ & $\begin{array}{l}\text { Intensity of flavour typical of bread } \\
\text { made with wheat flour }\end{array}$ & \multicolumn{2}{|c|}{ Cooked whole wheat $=100$} \\
\hline $\begin{array}{l}\text { Cooked Sorghum } \\
\text { flavour }\end{array}$ & $\begin{array}{l}\text { Intensity of flavour characteristic of } \\
\text { cooked sorghum }\end{array}$ & \multicolumn{2}{|c|}{ Cooked thick sorghum porridge $(\mathrm{pap})=100$} \\
\hline Cooked maize flavour & $\begin{array}{l}\text { Intensity of flavour characteristic of } \\
\text { cooked maize meal }\end{array}$ & \multicolumn{2}{|c|}{ Cooked thick maize porridge (pap) } \\
\hline Malty flavour & $\begin{array}{l}\text { Intensity of flavour associated with dark } \\
\text { beer with sour overtones. }\end{array}$ & \multicolumn{2}{|c|}{ Sorghum beer (Chibuku) $=100$} \\
\hline Musty & $\begin{array}{l}\text { The aromatics associated with wet } \\
\text { grain and damp earth }\end{array}$ & \multicolumn{2}{|c|}{ Wet sorghum grain soaked for $24 \mathrm{~h}=100$} \\
\hline Sweet taste & Intensity of basic taste of sucrose & \multicolumn{2}{|c|}{ Sucrose solution $16 \mathrm{~g} / \mathrm{L}=100$} \\
\hline Salty taste & Intensity of basic taste of table salt & \multicolumn{2}{|l|}{ Salt solution $5 \mathrm{~g} / \mathrm{L}=100$} \\
\hline Sour taste & Intensity of basic taste of lactic acid & \multicolumn{2}{|c|}{ Sorghum beer (Chibuku) $=100$} \\
\hline Bitter taste & $\begin{array}{l}\text { Intensity of basic taste of caffeine or } \\
\text { tannin. }\end{array}$ & \multicolumn{2}{|l|}{ Strong black tea $=100$} \\
\hline Astringent & $\begin{array}{l}\text { Intensity of a lingering sensation that } \\
\text { coats, dries and numbs the mouth, } \\
\text { palate and tongue. }\end{array}$ & \multicolumn{2}{|c|}{ Sorghum beer (Chibuku) $=100$} \\
\hline \multicolumn{4}{|c|}{ After swallow perception (scale: 0 = not intense; 100 = very intense ) } \\
\hline Overall aftertaste & $\begin{array}{l}\text { Intensity of flavour of bread after } \\
\text { swallowing }\end{array}$ & \multicolumn{2}{|c|}{$\begin{array}{l}0=\text { not intense; } 100=\text { very } \\
\text { intense }\end{array}$} \\
\hline Grainy residue & $\begin{array}{l}\text { The amount of grainy residue left in the } \\
\text { mouth after swallowing }\end{array}$ & \multicolumn{2}{|c|}{$\begin{array}{l}0=\text { No grain residue } 100= \\
\text { Extensive grain residue }\end{array}$} \\
\hline Bran residue & $\begin{array}{l}\text { The amount of bran residues left in the } \\
\text { mouth after swallowing }\end{array}$ & \multicolumn{2}{|c|}{$\begin{array}{l}0=\text { No fibrous residue } \\
100=\text { Extensive fibrous residue }\end{array}$} \\
\hline
\end{tabular}


Table 4 Mean Titratable acidity ${ }^{1}$ (TTA) and $\mathrm{pH}$ values of Sourdough from Wheat, Sorghum and Maize flours and corresponding Bread Dough Samples

\begin{tabular}{|c|c|c|c|c|c|c|c|}
\hline \multirow[b]{3}{*}{ Breads } & \multicolumn{5}{|c|}{ Sourdough } & \multicolumn{2}{|c|}{ Bread dough } \\
\hline & $\mathrm{pH}$ (Day 0) & $\mathrm{pH}$ (Day 1) & $\mathrm{pH}$ (Day 2) & TTA (Day 1) & TTA (Day 2) & $\mathrm{pH}$ & TTA \\
\hline & & & & & & \multicolumn{2}{|c|}{ Prior to steaming } \\
\hline Coarse milled whole wheat (CWWheat) & $6.28^{\mathrm{e}}$ & $5.27^{\mathrm{C}}$ & $4.23^{\mathrm{ab}}$ & $0.13^{\mathrm{e}}$ & $0.81^{\mathrm{b}}$ & $5.24^{\mathrm{a}}$ & $0.26^{\mathrm{bc}}$ \\
\hline Fine milled whole wheat (FWWheat) & $6.43^{\mathrm{bc}}$ & $5.75^{\mathrm{b}}$ & $4.17^{\mathrm{b}}$ & $0.20^{\mathrm{d}}$ & $0.73^{\mathrm{c}}$ & $5.10^{\mathrm{a}}$ & $0.26^{\mathrm{bc}}$ \\
\hline Commercial wheat (ComWheat) & $6.35^{\mathrm{de}}$ & $3.91^{\dagger}$ & $3.78^{\mathrm{e}}$ & $0.56^{\mathrm{a}}$ & $0.99^{\mathrm{a}}$ & $5.01^{a}$ & $0.22^{c}$ \\
\hline Whole grain red sorghum (WRSorg) & $6.38^{\mathrm{cd}}$ & $5.87^{\mathrm{a}}$ & $4.04^{\mathrm{C}}$ & $0.22^{\mathrm{d}}$ & $0.79^{\mathrm{b}}$ & $4.56^{\mathrm{b}}$ & $0.37^{\mathrm{ab}}$ \\
\hline Commercial red sorghum (ComRSorg) & $6.62^{\mathrm{a}}$ & $3.72^{\mathrm{g}}$ & $3.65^{f}$ & $0.59^{\mathrm{a}}$ & $0.50^{\mathrm{d}}$ & $4.64^{\mathrm{b}}$ & $0.33^{\mathrm{abc}}$ \\
\hline Whole grain white sorghum (WWhSorg) & $6.43^{\mathrm{cd}}$ & $5.13^{\mathrm{d}}$ & $4.26^{\mathrm{a}}$ & $0.28^{\mathrm{c}}$ & $0.47^{\mathrm{de}}$ & $5.04^{\mathrm{a}}$ & $0.41^{\mathrm{a}}$ \\
\hline Whole grain white maize (WWhMaize) & $6.36^{\text {cde }}$ & $3.92^{\dagger}$ & $3.88^{d}$ & $0.11^{\mathrm{e}}$ & $0.81^{\mathrm{b}}$ & $4.67^{\mathrm{b}}$ & $0.29^{\mathrm{bc}}$ \\
\hline Commercial white maize (ComWhMaize) & $6.51^{\mathrm{b}}$ & $4.09^{\mathrm{e}}$ & $4.08^{\mathrm{c}}$ & $0.40^{\mathrm{b}}$ & $0.41^{\mathrm{e}}$ & $4.59^{\mathrm{b}}$ & $0.34^{\mathrm{abc}}$ \\
\hline
\end{tabular}

${ }^{1}$ TTA values are expressed \% lactic acid (sourdough starter containing 1:1 ratio of flour: water) titrated to $\mathrm{pH} 6.3$.

Values are means. ${ }^{\text {abcdef }}$ Values in the same olumn with different letters are signifi antly different at $P \leq$ 
Sourdough and bread dough pH and TTA. The $\mathrm{pH}$ of the water:flour slurries on day 0 ranged from 6.28-6.62 (Table 4). A substantial variation in $\mathrm{pH}$ of the sourdoughs (3.91 5.87 ) were noted after one day. On day 2 , the pHs were more similar at $3.65-4.26$. Final sourdough TTAs of 0.4 to $1 \%$ and 0.2 to $0.4 \%$ in bread dough prior to steam cooking, were measured. No specific cereal type related acidification patterns were observed.

Texture profile analysis curves and bread appearance. Figures 2 - 5 provide photos of the breads as well as the results of texture analysis and specific volume measurements. The differences in bread shape, volume, crumb structure and colour are obvious. Wheat breads had round tops showing a gap or crack on the sides (Figure 2). Non-wheat breads were generally flat with more compact structures. Wheat breads had a higher specific volume compared to sorghum (Figure 3) and maize breads (Figure 4). For wheat bread the finer the flour the higher the specific volume (Figure 2).

The colour parameters of bread crumb are shown in Table 5. As expected, red sorghum bread were more red $\left(a^{*}\right)$ for both skin and crumb compared to the other breads. The skin and crumb of steamed maize breads were whitest with the highest $L^{*}$ values and hue angles. The lowest $L^{*}$ value indicating darkest colour was recorded for WRSorg bread. WWhMaize bread and ComWheat bread were more yellow on the skin with the highest $b^{*}$ values. In general, breads prepared using commercial flours were lighter in colour than crumbs of breads prepared from self-milled whole grain flours. Whole grain breads showed fibrous substances causing speckled appearance. The chroma and hue angle values for both skin and crumb differed significantly $(p<0.05)$ between breads. Maize breads had significantly higher hue angles. Maize breads also had lowest skin and crumb a-values. The crumb colour for CWWheat bread and WWhSorg bread did not differ significantly $(p>0.05)$ for all colour parameters. In general the chroma values of bread crumb for ComWhMaize, WRSorg, ComWheat and CWWheat bread were similar but significantly higher $(p<0.05)$ than the other breads. 


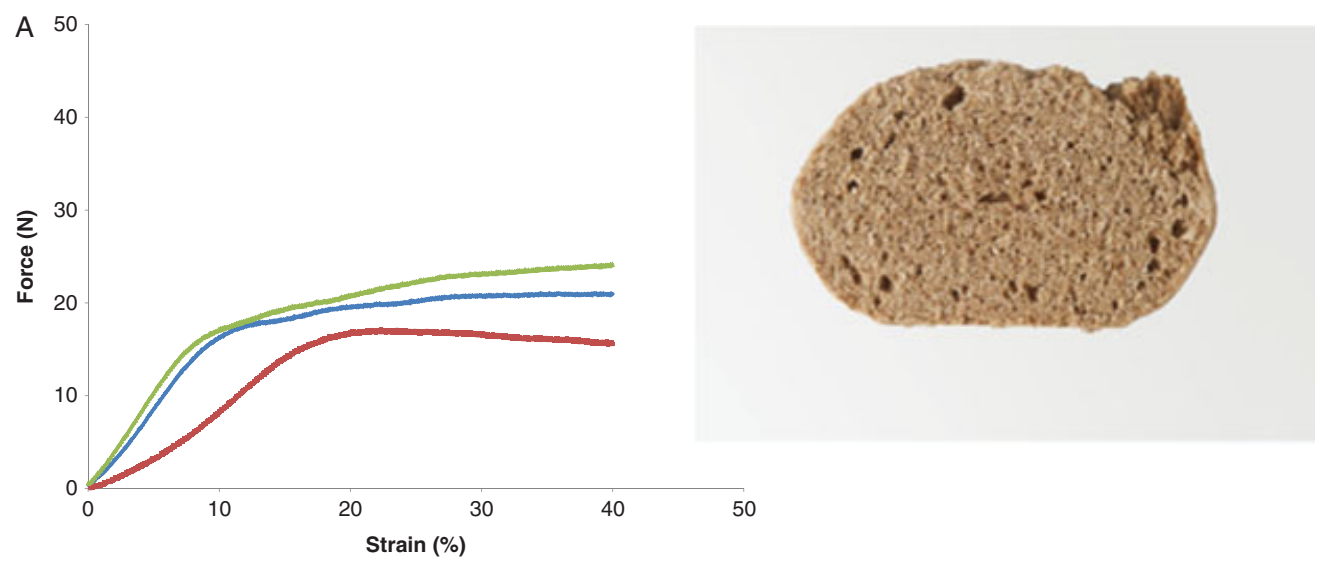

Specific

Volume

$2.2^{\mathrm{C}}$

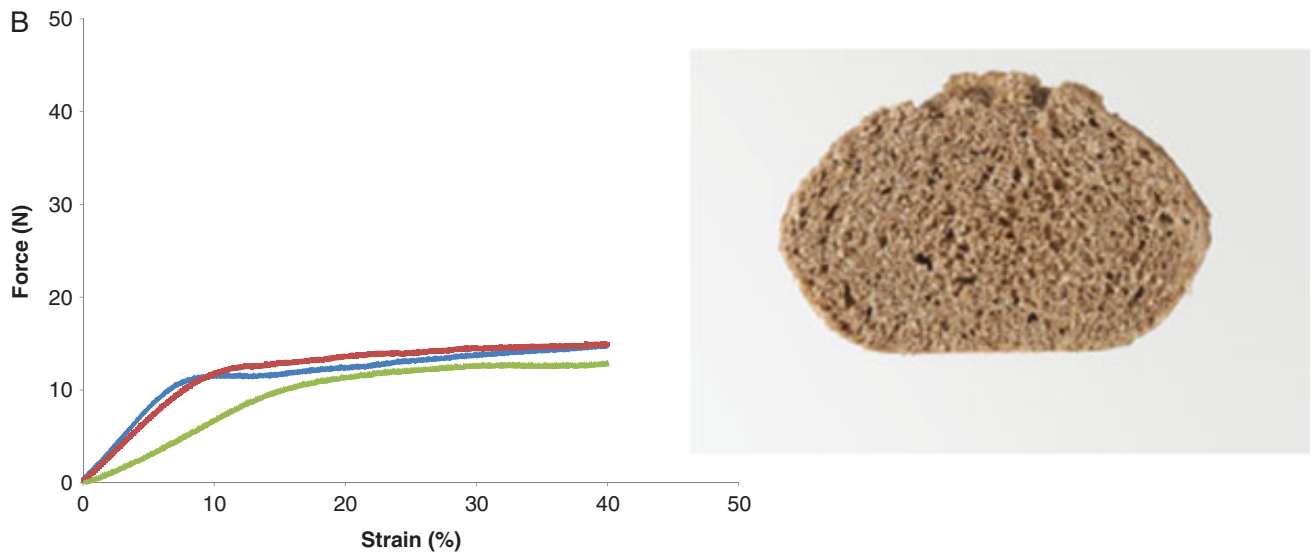

$2.4^{\mathrm{b}}$

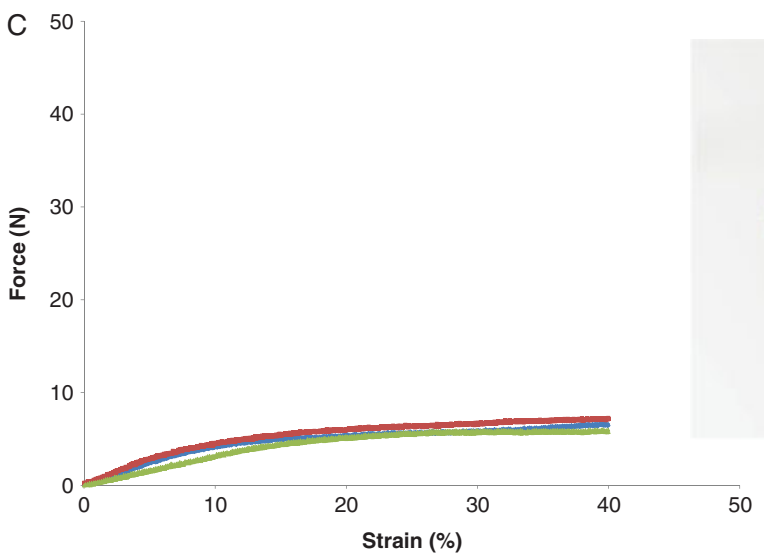

Figure 2. Characteristics of wheat breads, showing visual properties, specific volume and texture profiles (force to deform) at left (blue), centre (red) and right (green) positions of breads: A, coarsely milled whole wheat bread (CWWheat); B, finely milled whole wheat bread (FWWheat); C, commercial wheat bread (ComWheat). 


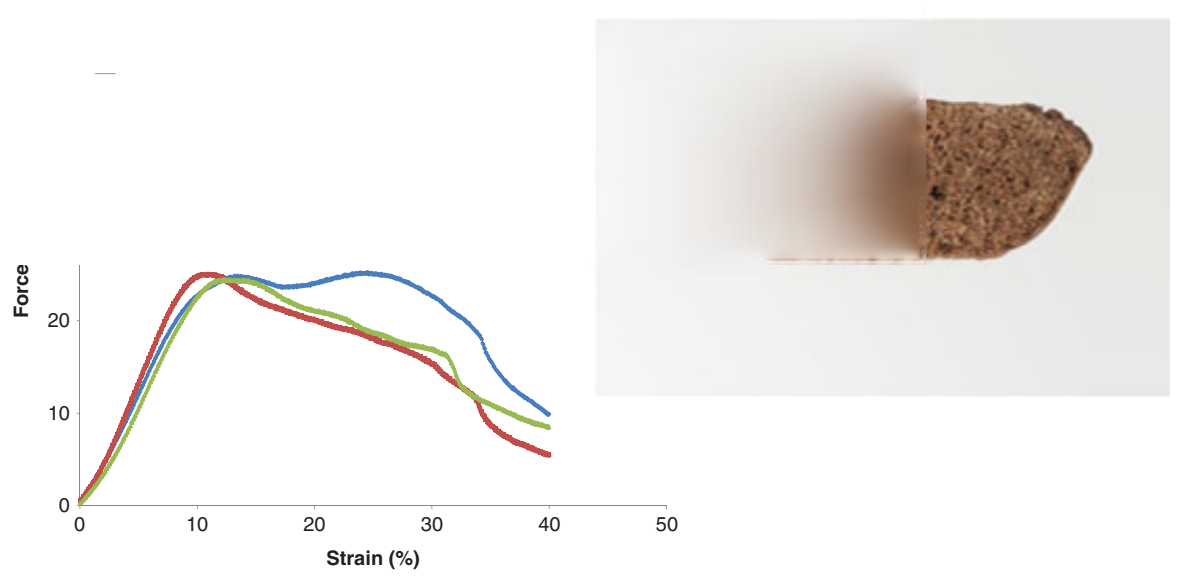

Specific

Volume

$1.7^{\mathrm{d}}$

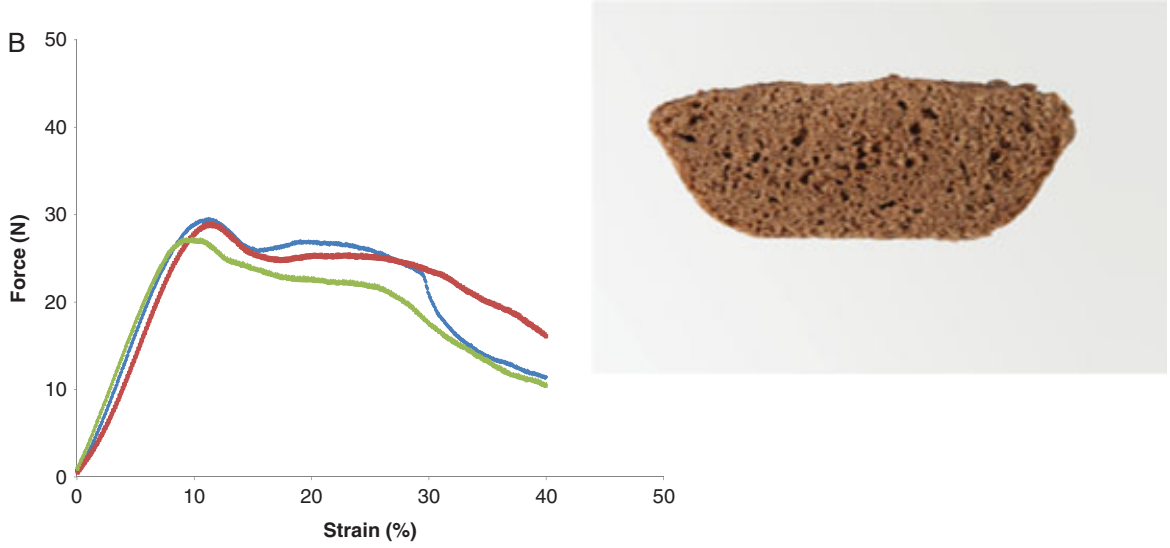

$1.6^{\mathrm{d}}$

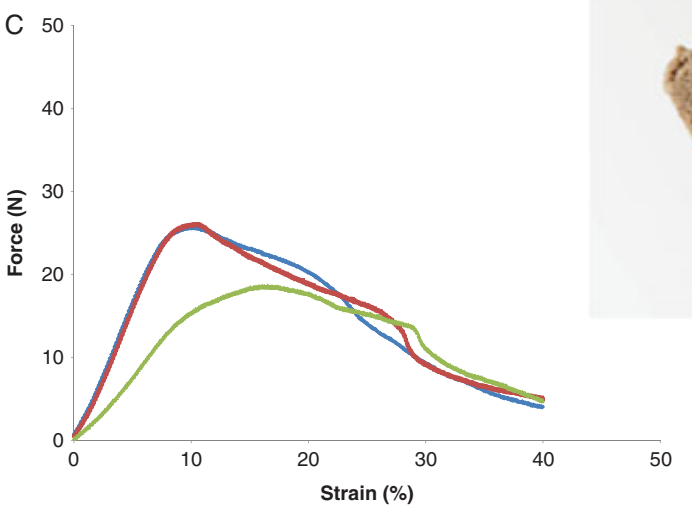

Figure 3. Characteristics of sorghum breads, showing visual properties, specific volume and texture profiles (force to deform) at left (blue), centre (red) and right (green) positions of breads: A, whole grain red sorghum bread (WRSorg); B, commercial red sorghum bread (ComRSorg); C, whole grain white sorghum bread (WWhSorg). 


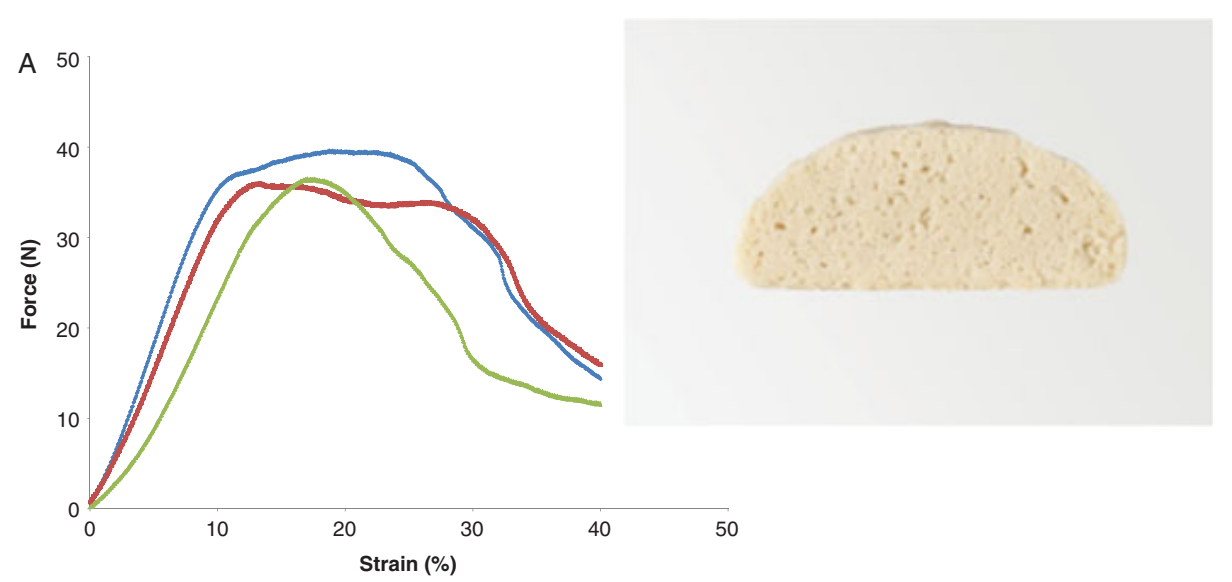

Specific

Volume

$1.2^{f}$

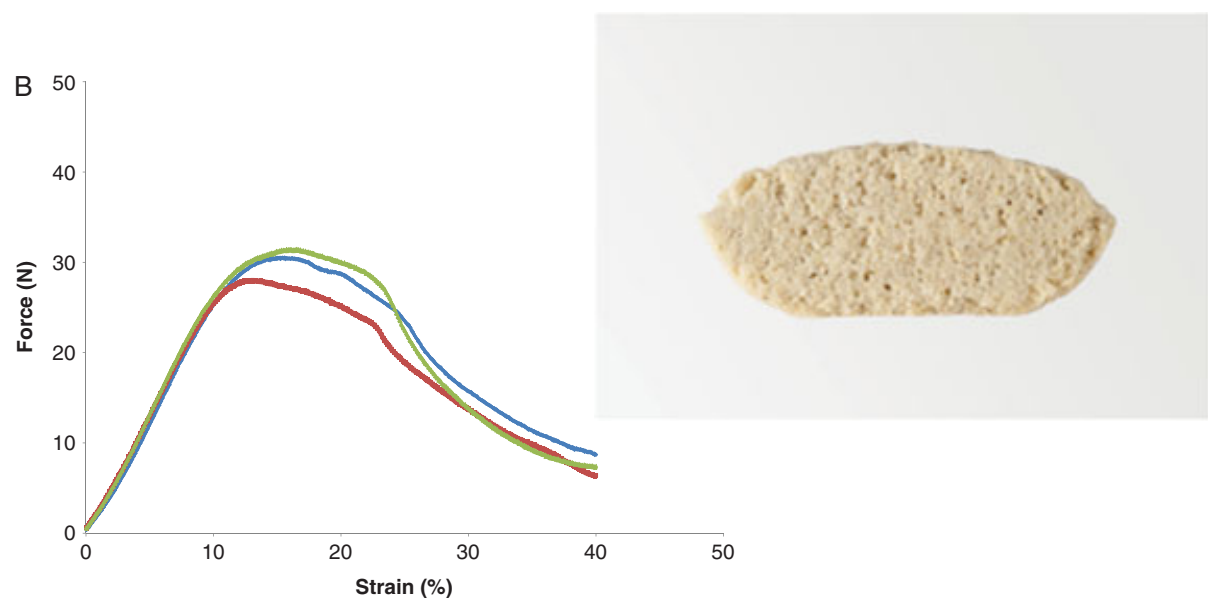

Figure 4. Characteristics of maize breads, showing visual properties, specific volume and texture profiles (force to deform) at left (blue), centre (red) and right (green) positions of breads: A, whole grain white maize bread (WWhMaize); B, commercial special white maize bread (ComWhMaize). 

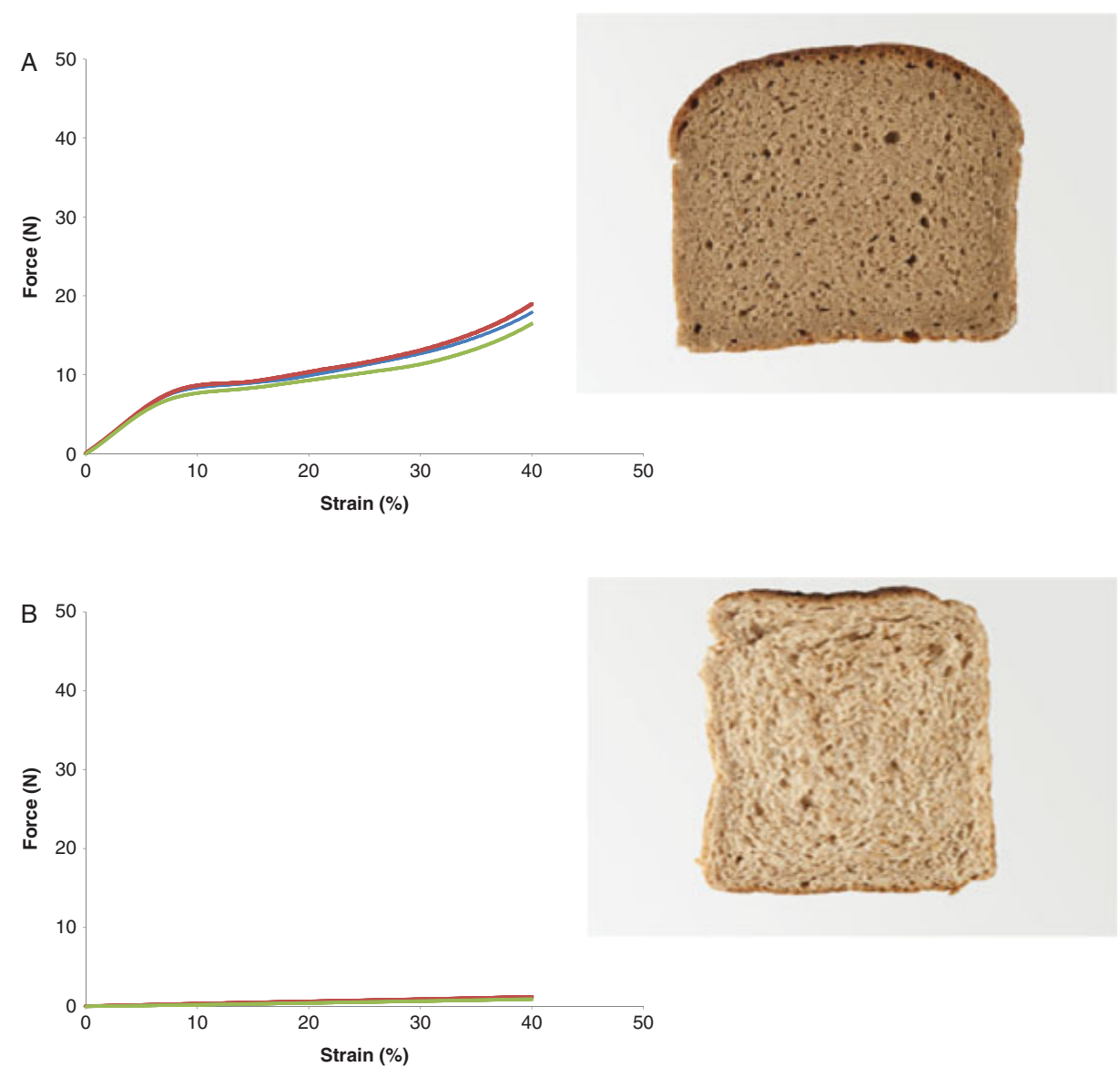

Figure 5. Characteristics of standard breads, showing visual properties and texture profiles (force to deform) at left (blue), centre (red) and right (green) positions of breads: A, standard rye bread (100\% plain); B, standard whole wheat bread. 


\begin{tabular}{|c|c|c|c|c|c|}
\hline Type of Bread & $L^{*}$ & $a^{*}$ & $b^{*}$ & Chroma & Hue \\
\hline \multicolumn{6}{|l|}{ Skin } \\
\hline Coarse milled whole wheat (CWWheat) & $64.83^{c}$ & $8.70^{\mathrm{b}}$ & $15.05^{b}$ & $17.39^{\mathrm{ab}}$ & $59.94^{\mathrm{C}}$ \\
\hline Fine milled whole wheat (FWWheat) & $60.09^{d}$ & $8.71^{b}$ & $12.24^{\mathrm{C}}$ & $15.03^{\mathrm{bcd}}$ & $54.29^{d}$ \\
\hline Commercial wheat (ComWheat) & $77.83^{\mathrm{b}}$ & $5.13^{\mathrm{C}}$ & $16.26^{\mathrm{ab}}$ & $17.07^{\mathrm{abc}}$ & $72.45^{\mathrm{b}}$ \\
\hline Whole grain red sorghum (WRSorg) & $48.18^{f}$ & $11.35^{a}$ & $5.89^{\mathrm{e}}$ & $12.80^{\mathrm{d}}$ & $27.33^{f}$ \\
\hline Commercial red sorghum (ComRSorg) & $55.57^{e}$ & $11.72^{a}$ & $9.60^{d}$ & $15.16^{\mathrm{bcd}}$ & $39.32^{\mathrm{e}}$ \\
\hline Whole grain white sorghum (WWhSorg) & $64.47^{\mathrm{C}}$ & $7.50^{\mathrm{b}}$ & $12.32^{\mathrm{c}}$ & $14.43^{\mathrm{d}}$ & $58.52^{\mathrm{C}}$ \\
\hline Whole grain white maize (WWhMaize) & $89.25^{\mathrm{a}}$ & $-0.74^{d}$ & $18.42^{\mathrm{a}}$ & $18.44^{\mathrm{a}}$ & $92.27^{\mathrm{a}}$ \\
\hline Commercial white maize (ComWhMaize) & $91.85^{\mathrm{a}}$ & $-1.24^{\mathrm{d}}$ & $14.52^{\mathrm{bc}}$ & $14.57^{\mathrm{cd}}$ & $94.94^{a}$ \\
\hline Rye (standard) & nd & nd & nd & nd & nd \\
\hline Whole wheat (standard) & nd & nd & nd & nd & nd \\
\hline \multicolumn{6}{|l|}{ Crumb } \\
\hline Coarse milled whole wheat (CWWheat) & $46.36^{\mathrm{C}}$ & $4.21^{b}$ & $8.11^{\mathrm{c}}$ & $9.14^{\mathrm{de}}$ & $62.51^{f}$ \\
\hline Fine milled whole wheat (FWWheat) & $43.79^{d}$ & $4.00^{\mathrm{b}}$ & $6.64^{d}$ & $7.76^{f}$ & $58.91^{f}$ \\
\hline Commercial wheat (ComWheat) & $58.56^{\mathrm{b}}$ & $1.98^{\mathrm{C}}$ & $9.37^{b}$ & $9.58^{\mathrm{cd}}$ & $78.08^{\mathrm{C}}$ \\
\hline Whole grain red sorghum (WRSorg) & $38.40^{f}$ & $7.47^{\mathrm{a}}$ & $5.78^{e}$ & $9.45^{\mathrm{cd}}$ & $37.75^{\mathrm{g}}$ \\
\hline Commercial red sorghum (ComRSorg) & $41.01^{\mathrm{e}}$ & $7.03^{a}$ & $5.74^{e}$ & $9.08^{\mathrm{de}}$ & $39.23^{9}$ \\
\hline Whole grain white sorghum (WWhSorg) & $47.99^{\mathrm{C}}$ & $4.09^{b}$ & $7.67^{\mathrm{c}}$ & $8.69^{\mathrm{e}}$ & $61.96^{f}$ \\
\hline Whole grain white maize (WWhMaize) & $65.88^{a}$ & $-0.71^{d}$ & $10.92^{\mathrm{a}}$ & $10.94^{b}$ & $93.73^{b}$ \\
\hline Commercial white maize (ComWhMaize) & $66.79^{a}$ & $-1.29^{d}$ & $9.20^{b}$ & $9.30^{\text {de }}$ & $97.94^{a}$ \\
\hline Rye (standard) & $46.09^{\mathrm{cd}}$ & $4.02^{b}$ & $9.26^{b}$ & $10.11^{\mathrm{c}}$ & $66.48^{\mathrm{e}}$ \\
\hline Whole wheat (standard) & $59.24^{b}$ & $3.98^{b}$ & $11.58^{\mathrm{a}}$ & $12.25^{\mathrm{a}}$ & $71.12^{d}$ \\
\hline
\end{tabular}

abcdef Values for $s$ in or rum in the same olumn with different letters are signifi antly different at $p \leq$

nd not determined 
The wheat and non-wheat breads displayed differences in crumb structure and texture parameters. The non-wheat breads required higher maximum force to deform than wheat and standard breads. The texture graphs (Figures 2 - 5) reflect three types of texture properties: plastic deformation for wheat breads (Figure 2), brittle deformation for the maize and sorghum breads (Figure 3 - 4) and elastic deformation for standard breads (Figure 5). Rye bread was denser and harder compared to standard whole wheat bread. The crumb structure of ComWhMaize bread was firmer (40N) than WWhMaize bread (31N) (Figure 4).

The fineness of wheat flour had an effect on the hardness of wheat bread. Figure 2 shows that ComWheat bread required less compression force $(10 \mathrm{~N})$ compared to FWWheat bread $(20 N)$ and CWWheat bread $(25 N)$. Bread position did not have an influence on the force required to deform non-wheat breads (results not shown). However, CWWheat was softer at centre position than at left and right positions.

Descriptive sensory analysis. All sensory attributes, except firmness of crumb and astringen y showed signifi an t differen e $s(p \leq \quad$ among the reads (Table 6). PCA plots give insight on the differences in properties of the breads (Figure 6). The grouping and separation of breads on the PCA plot is mostly explained by the cereal used. The first three $\mathrm{P}$ 's explained a total varian e of $88 \% \mathrm{P}$, explaining $7 \%$ of the variation, separated the wheat breads and the rye standard with more cohesive, springy crumb, more intense whole wheat flavour and fresh baked wheat aroma on the right, from the sorghum and maize breads on the left of the loading plot. The limited number of attributes on the right (score plot) indicates the more bland flavour of the wheat bread and commercial rye standard. In contrast, the sorghum and maize breads on the left of the plot had more complex flavour profiles showing more intense sour taste, and more malty, musty, fermented aroma and flavour than the wheat breads. The non-wheat breads on the left were also more crumbly with rough bread crumbs, dry, grainy and chewy textures. The breads felt heavier and rougher in the mouth. WWhMaize bread in particular, was more fibrous than the other 
Table 6 Mean Descriptive Sensory Ratings for Wheat, Sorghum and Maize steamed breads

\begin{tabular}{|c|c|c|c|c|c|c|c|c|c|c|c|c|}
\hline \multirow[t]{2}{*}{ Attribute } & \multicolumn{10}{|c|}{ Type of bread } & \multirow[b]{2}{*}{ F-value } & \multirow[b]{2}{*}{$p$-value } \\
\hline & $\begin{array}{l}\mathrm{CW} \\
\text { Wheat }\end{array}$ & $\begin{array}{l}\text { FW } \\
\text { Wheat }\end{array}$ & $\begin{array}{l}\text { Com } \\
\text { Wheat }\end{array}$ & $\begin{array}{l}\text { WR } \\
\text { Sorg }\end{array}$ & $\begin{array}{l}\text { ComR } \\
\text { Sorg }\end{array}$ & $\begin{array}{l}\text { WWh } \\
\text { Sorg }\end{array}$ & $\begin{array}{l}\text { WWh } \\
\text { Maize }\end{array}$ & $\begin{array}{l}\text { ComWh } \\
\text { Maize }\end{array}$ & $\begin{array}{l}\text { Rye } \\
\text { standard }\end{array}$ & $\begin{array}{l}\text { Whole } \\
\text { wheat } \\
\text { bread } \\
\text { standard }\end{array}$ & & \\
\hline \multicolumn{13}{|l|}{ Aroma } \\
\hline Overall aroma & $49^{c d}$ & $61^{\mathrm{abc}}$ & $46^{\mathrm{de}}$ & $69^{\mathrm{a}}$ & $70^{\mathrm{a}}$ & $55^{\mathrm{bcd}}$ & $63^{\mathrm{ab}}$ & $61^{\mathrm{abc}}$ & $61^{\mathrm{abc}}$ & $35^{\mathrm{e}}$ & 4.96 & *** \\
\hline Fermented aroma & $31^{d}$ & $37^{\mathrm{cd}}$ & $26^{d}$ & $63^{\mathrm{a}}$ & $66^{a}$ & $49^{b}$ & $44^{\mathrm{bc}}$ & $46^{\mathrm{bc}}$ & $31^{\mathrm{d}}$ & $9^{e}$ & 12.52 & *** \\
\hline Yeasty aroma & $22^{\mathrm{b}}$ & $22^{\mathrm{b}}$ & $29^{\mathrm{ab}}$ & $29^{a b}$ & $35^{\mathrm{a}}$ & $30^{\mathrm{ab}}$ & $29^{a b}$ & $26^{\mathrm{ab}}$ & $9^{c}$ & $18^{\mathrm{bc}}$ & 2.79 & *** \\
\hline Malty aroma & $18^{\mathrm{bc}}$ & $20^{\mathrm{bc}}$ & $9^{\text {cd }}$ & $37^{\mathrm{a}}$ & $35^{\mathrm{a}}$ & $26^{\mathrm{ab}}$ & $15^{\mathrm{bc}}$ & $13^{\mathrm{cd}}$ & $11^{\mathrm{cd}}$ & $2^{d}$ & 5.75 & *** \\
\hline Musty/earthy aroma & $22^{\mathrm{ab}}$ & $15^{\mathrm{bcd}}$ & $15^{\mathrm{bcd}}$ & $28^{a}$ & $30^{a}$ & $20^{\mathrm{abc}}$ & $19^{\mathrm{abc}}$ & $15^{\mathrm{bcd}}$ & $9^{\text {cd }}$ & $5^{\mathrm{d}}$ & 2.5 & ** \\
\hline Cereals/grain aroma & $18^{\mathrm{a}}$ & $19^{\mathrm{a}}$ & $18^{\mathrm{a}}$ & $14^{\mathrm{ab}}$ & $13^{\mathrm{ab}}$ & $18^{\mathrm{a}}$ & $14^{\mathrm{ab}}$ & $8^{\mathrm{b}}$ & $6^{\mathrm{b}}$ & $18^{\mathrm{a}}$ & 1.89 & * \\
\hline Herbal aroma & $12^{\mathrm{b}}$ & $11^{\mathrm{b}}$ & $3^{b}$ & $9^{b}$ & $7^{\mathrm{b}}$ & $7^{\mathrm{b}}$ & $4^{b}$ & $3^{b}$ & $48^{\mathrm{a}}$ & $3^{\mathrm{b}}$ & 9.91 & *** \\
\hline Cooked sorghum aroma & $24^{\mathrm{b}}$ & $24^{\mathrm{b}}$ & $7^{c}$ & $46^{a}$ & $47^{\mathrm{a}}$ & $39^{\mathrm{a}}$ & $2^{c}$ & $2^{c}$ & $9^{c}$ & $1^{\mathrm{c}}$ & 19.8 & *** \\
\hline Fresh baked wheat bread aroma & $21^{\text {cd }}$ & $26^{\mathrm{c}}$ & $48^{\mathrm{b}}$ & $6^{f}$ & $11^{\text {ef }}$ & $12^{\text {def }}$ & $11^{\text {def }}$ & $18^{\text {cde }}$ & $15^{\text {def }}$ & $62^{\mathrm{a}}$ & 22.59 & *** \\
\hline Dairy sour aroma & $8^{c}$ & $14^{\mathrm{bc}}$ & $15^{\mathrm{bc}}$ & $13^{\mathrm{bc}}$ & $12^{\mathrm{bc}}$ & $10^{\mathrm{C}}$ & $23^{\mathrm{ab}}$ & $28^{\mathrm{a}}$ & $12^{\mathrm{bc}}$ & $9^{c}$ & 1.96 & * \\
\hline \multicolumn{13}{|l|}{ Texture } \\
\hline Dryness of bread crumb & $42^{\mathrm{a}}$ & $38^{\mathrm{ab}}$ & $27^{\mathrm{bc}}$ & $45^{\mathrm{a}}$ & $46^{a}$ & $45^{\mathrm{a}}$ & $37^{\mathrm{ab}}$ & $43^{a}$ & $18^{\mathrm{cd}}$ & $14^{\mathrm{d}}$ & 7.24 & *** \\
\hline Crumbliness of bread crumb & $31^{d}$ & $33^{d}$ & $17^{\mathrm{e}}$ & $71^{\mathrm{ab}}$ & $63^{\mathrm{bc}}$ & $77^{\mathrm{a}}$ & $77^{\mathrm{a}}$ & $59^{c}$ & $4^{f}$ & $4^{f}$ & 54.3 & *** \\
\hline Springiness of bread crumb & $46^{c}$ & $52^{\mathrm{bc}}$ & $65^{\mathrm{a}}$ & $10^{d}$ & $12^{d}$ & $5^{d}$ & $9^{d}$ & $7^{d}$ & $63^{\mathrm{ab}}$ & $48^{\mathrm{c}}$ & 22.08 & *** \\
\hline Firmness of first bite & $40^{\mathrm{ab}}$ & $37^{\mathrm{b}}$ & $32^{\mathrm{bcd}}$ & $19^{\mathrm{de}}$ & $23^{\text {cdeb }}$ & $17^{\mathrm{e}}$ & $21^{\mathrm{de}}$ & $35^{\mathrm{bc}}$ & $53^{\mathrm{a}}$ & $28^{\text {bcde }}$ & 5.23 & *** \\
\hline Roughness of crumb & $36^{b}$ & $32^{b}$ & $14^{\mathrm{c}}$ & $63^{a}$ & $59^{a}$ & $60^{a}$ & $59^{a}$ & $56^{a}$ & $6^{c}$ & $7^{c}$ & 29.77 & $* * *$ \\
\hline Dryness & $43^{\mathrm{bc}}$ & $33^{c}$ & $21^{\mathrm{d}}$ & $60^{a}$ & $58^{\mathrm{a}}$ & $55^{a}$ & $50^{\mathrm{ab}}$ & $52^{\mathrm{ab}}$ & $13^{d}$ & $15^{d}$ & 17.21 & *** \\
\hline Cohesiveness & $42^{b}$ & $46^{\mathrm{b}}$ & $65^{\mathrm{a}}$ & $24^{\mathrm{c}}$ & $21^{\mathrm{c}}$ & $25^{\mathrm{c}}$ & $26^{c}$ & $27^{\mathrm{c}}$ & $71^{\mathrm{a}}$ & $72^{\mathrm{a}}$ & 14.29 & *** \\
\hline Graininess & $28^{\mathrm{b}}$ & $23^{b}$ & $8^{c}$ & $75^{\mathrm{a}}$ & $73^{\mathrm{a}}$ & $74^{\mathrm{a}}$ & $73^{a}$ & $69^{a}$ & $7^{\mathrm{c}}$ & $9^{c}$ & 46.12 & *** \\
\hline Heaviness & $41^{\mathrm{abc}}$ & $39^{\mathrm{bc}}$ & $29^{c}$ & $50^{\mathrm{ab}}$ & $52^{a}$ & $49^{\mathrm{ab}}$ & $48^{\mathrm{ab}}$ & $52^{\mathrm{a}}$ & $44^{\mathrm{ab}}$ & $14^{d}$ & 5.73 & *** \\
\hline Firmness of crumb & $34^{\mathrm{ab}}$ & $32^{\mathrm{ab}}$ & $36^{\mathrm{ab}}$ & $28^{\mathrm{b}}$ & $32^{\mathrm{ab}}$ & $32^{\mathrm{ab}}$ & $32^{a b}$ & $36^{\mathrm{ab}}$ & $43^{a}$ & $28^{\mathrm{b}}$ & 0.85 & ns \\
\hline Chewiness & $51^{\mathrm{bc}}$ & $42^{\mathrm{cd}}$ & $42^{\mathrm{cd}}$ & $63^{\mathrm{ab}}$ & $69^{\mathrm{a}}$ & $72^{\mathrm{a}}$ & $68^{a}$ & $61^{\mathrm{ab}}$ & $38^{d}$ & $40^{c d}$ & 7.53 & $* * *$ \\
\hline Fibrousness & $33^{\mathrm{bc}}$ & $34^{\mathrm{bc}}$ & $18^{\mathrm{d}}$ & $38^{\mathrm{b}}$ & $33^{\mathrm{bc}}$ & $38^{\mathrm{b}}$ & $73^{\mathrm{a}}$ & $30^{\mathrm{bcd}}$ & $2^{\mathrm{e}}$ & $22^{\text {cd }}$ & 10.8 & *** \\
\hline
\end{tabular}

Values in the same row with different letters ${ }^{\text {abcde }}$ are significantly different at ${ }^{*} p<0.05,{ }^{* * *} p<0.01,{ }^{* * *} p<0.001$. ns $=$ not signicantly different. CWWheat $=$ Coarse whole wheat, FWWheat $=$ Fine whole wheat, ComWheat $=$ Commercial wheat, WRSorg= Whole red sorghum, ComRSorg= Commercial red sorghum, WWhSorg= Whole white sorghum,

WWhMaize $=$ Whole white maize, ComWhMaize $=$ Commercial white maize. 
Table 6 (Continued) Mean descriptive sensory ratings for standardized traditional Basotho of wheat, sorghum maize and steamed breads

\begin{tabular}{|c|c|c|c|c|c|c|c|c|c|c|c|c|}
\hline \multirow[t]{2}{*}{ Attribute } & \multicolumn{10}{|c|}{ Type of bread } & \multirow{2}{*}{\multicolumn{2}{|c|}{ P-value }} \\
\hline & $\begin{array}{l}\text { CW } \\
\text { Wheat }\end{array}$ & $\begin{array}{l}\text { FW } \\
\text { Wheat }\end{array}$ & $\begin{array}{l}\text { Com } \\
\text { Wheat }\end{array}$ & $\begin{array}{l}\text { WR } \\
\text { Sorg }\end{array}$ & $\begin{array}{l}\text { ComR } \\
\text { Sorg }\end{array}$ & $\begin{array}{l}\text { WWh } \\
\text { Sorg }\end{array}$ & $\begin{array}{l}\text { WWh } \\
\text { Maize }\end{array}$ & $\begin{array}{l}\text { ComWh } \\
\text { Maize }\end{array}$ & Rye & $\begin{array}{l}\text { Whole } \\
\text { wheat } \\
\text { standard }\end{array}$ & & \\
\hline \multicolumn{13}{|l|}{ Flavour } \\
\hline Overall flavour & $44^{\mathrm{cd}}$ & $52^{\mathrm{bc}}$ & $46^{\mathrm{bcd}}$ & $65^{\mathrm{a}}$ & $65^{a}$ & $53^{\mathrm{bc}}$ & $55^{\mathrm{abc}}$ & $57^{\mathrm{ab}}$ & $66^{a}$ & $40^{d}$ & 4.33 & $* * *$ \\
\hline Cooked whole wheat flavour & $27^{\mathrm{b}}$ & $28^{b}$ & $47^{\mathrm{a}}$ & $8^{c}$ & $13^{c}$ & $8^{c}$ & $11^{\mathrm{c}}$ & $11^{\mathrm{c}}$ & $10^{c}$ & $47^{\mathrm{a}}$ & 11.91 & *** \\
\hline Cooked sorghum flavour & $17^{\mathrm{bc}}$ & $21^{\mathrm{b}}$ & $8^{\mathrm{cd}}$ & $46^{\mathrm{a}}$ & $47^{\mathrm{a}}$ & $43^{\mathrm{a}}$ & $4^{d}$ & $4^{d}$ & $7^{\mathrm{cd}}$ & $2^{d}$ & 17.68 & $* * *$ \\
\hline Cooked maize flavour & $7^{\mathrm{b}}$ & $6^{\mathrm{b}}$ & $6^{b}$ & $8^{b}$ & $8^{b}$ & $9^{b}$ & $63^{\mathrm{a}}$ & $56^{\mathrm{a}}$ & $4^{b}$ & $0^{b}$ & 38.49 & $* * *$ \\
\hline Malty flavour & $12^{\mathrm{c}}$ & $15^{\mathrm{bc}}$ & $7^{\text {cd }}$ & $28^{\mathrm{a}}$ & $26^{\mathrm{a}}$ & $23^{\mathrm{ab}}$ & $12^{\mathrm{c}}$ & $9^{\text {cd }}$ & $9^{\text {cd }}$ & $1^{d}$ & 5.45 & $* * *$ \\
\hline Musty flavour & $18^{\mathrm{bcd}}$ & $18^{\mathrm{abcd}}$ & $11^{\text {de }}$ & $31^{a}$ & $29^{\mathrm{ab}}$ & $24^{\mathrm{abc}}$ & $18^{\mathrm{bcd}}$ & $15^{\mathrm{cd}}$ & $13^{\text {cde }}$ & $1 e$ & 3.15 & $* * *$ \\
\hline Sweet taste & $4^{\text {cd }}$ & $4^{\text {bcd }}$ & $10^{\mathrm{ab}}$ & $3^{\mathrm{d}}$ & $10^{\mathrm{abc}}$ & $3^{d}$ & $5^{\mathrm{bcd}}$ & $14^{\mathrm{a}}$ & $7^{\mathrm{bcd}}$ & $5^{\mathrm{bcd}}$ & 2.34 & ** \\
\hline Salty taste & $20^{\mathrm{b}}$ & $22^{b}$ & $21^{b}$ & $18^{\mathrm{b}}$ & $17^{\mathrm{b}}$ & $20^{\mathrm{b}}$ & $23^{\mathrm{b}}$ & $19^{b}$ & $36^{\mathrm{a}}$ & $19^{\mathrm{b}}$ & 1.81 & * \\
\hline Bitter taste & $3^{\mathrm{bcd}}$ & $3^{\mathrm{bc}}$ & $1^{\text {cd }}$ & $7^{\mathrm{a}}$ & $4^{\mathrm{ab}}$ & $2 b^{c d}$ & $4^{\mathrm{ab}}$ & $0^{\text {cd }}$ & $4^{\mathrm{ab}}$ & $0^{d}$ & 2.9 & $* * *$ \\
\hline Sour taste & $17^{\mathrm{cd}}$ & $24^{\mathrm{bcd}}$ & $18^{\mathrm{cd}}$ & $36^{\mathrm{a}}$ & $37^{\mathrm{a}}$ & $30^{\mathrm{ab}}$ & $28^{\mathrm{abc}}$ & $21^{\mathrm{bcd}}$ & $15^{\mathrm{de}}$ & $4^{\mathrm{e}}$ & 5.67 & *** \\
\hline Astringent & $17^{\mathrm{abc}}$ & $17^{\mathrm{abc}}$ & $11^{\mathrm{bc}}$ & $20^{\mathrm{ab}}$ & $24^{\mathrm{a}}$ & $23^{\mathrm{ab}}$ & $24^{\mathrm{a}}$ & $15^{\mathrm{abc}}$ & $12^{\mathrm{abc}}$ & $5^{\mathrm{c}}$ & 1.6 & ns \\
\hline \multicolumn{13}{|l|}{ After taste } \\
\hline Overall aftertaste & $38^{\mathrm{bc}}$ & $45^{\mathrm{ab}}$ & $32^{\mathrm{bc}}$ & $53^{\mathrm{a}}$ & $53^{\mathrm{a}}$ & $43^{\mathrm{abc}}$ & $45^{\mathrm{ab}}$ & $37^{\mathrm{bc}}$ & $55^{\mathrm{a}}$ & $30^{c}$ & 2.72 & ** \\
\hline Presence of grainy residue & $19^{b}$ & $16^{\mathrm{bc}}$ & $6^{\mathrm{bcd}}$ & $59^{a}$ & $62^{a}$ & $56^{\mathrm{a}}$ & $52^{\mathrm{a}}$ & $55^{\mathrm{a}}$ & $4^{\mathrm{cd}}$ & $2^{d}$ & 24.36 & *** \\
\hline Presence of bran residue & $21^{b}$ & $23^{b}$ & $15^{\mathrm{b}}$ & $21^{\mathrm{b}}$ & $17^{\mathrm{b}}$ & $20^{b}$ & $5^{\mathrm{a}}$ & $13^{b}$ & $1^{c}$ & $14^{\mathrm{b}}$ & 8.6 & $* * *$ \\
\hline
\end{tabular}

Values in the same row with different letters ${ }^{\text {abcde }}$ are significantly different at $* p<0.05, * * * p<0.01, * * * p<0.001$. ns $=$ not signicantly different. CWWheat $=$ Coarse whole wheat, FWWheat $=$ Fine whole wheat, ComWheat $=$ Commercial wheat, WRSorg= Whole red sorghum, ComRSorg= Commercial red sorghum, WWhSorg= Whole white sorghum, WWhMaize= Whole white maize, ComWhMaize= Commercial white maize. 


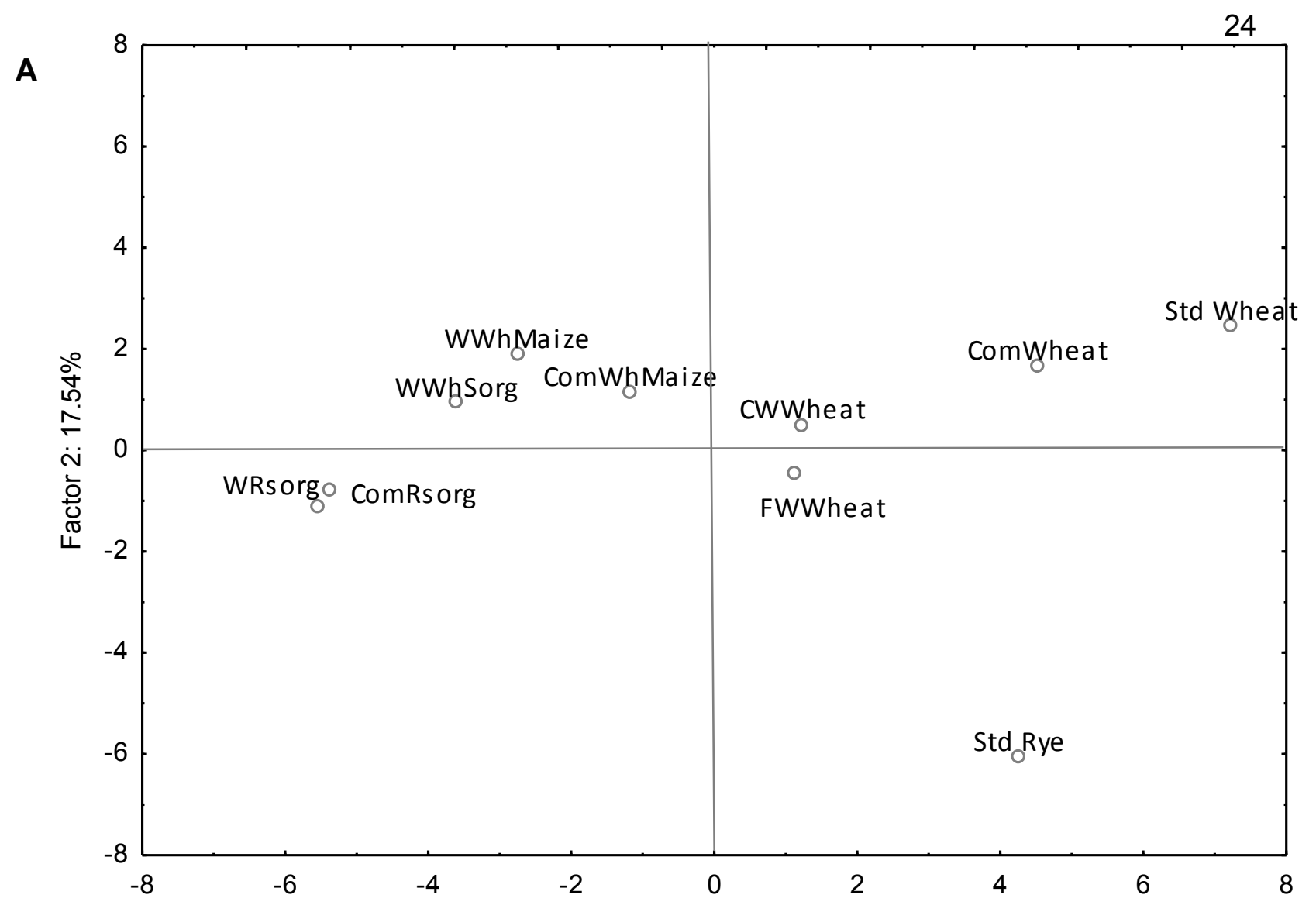

Factor 1: $57.20 \%$

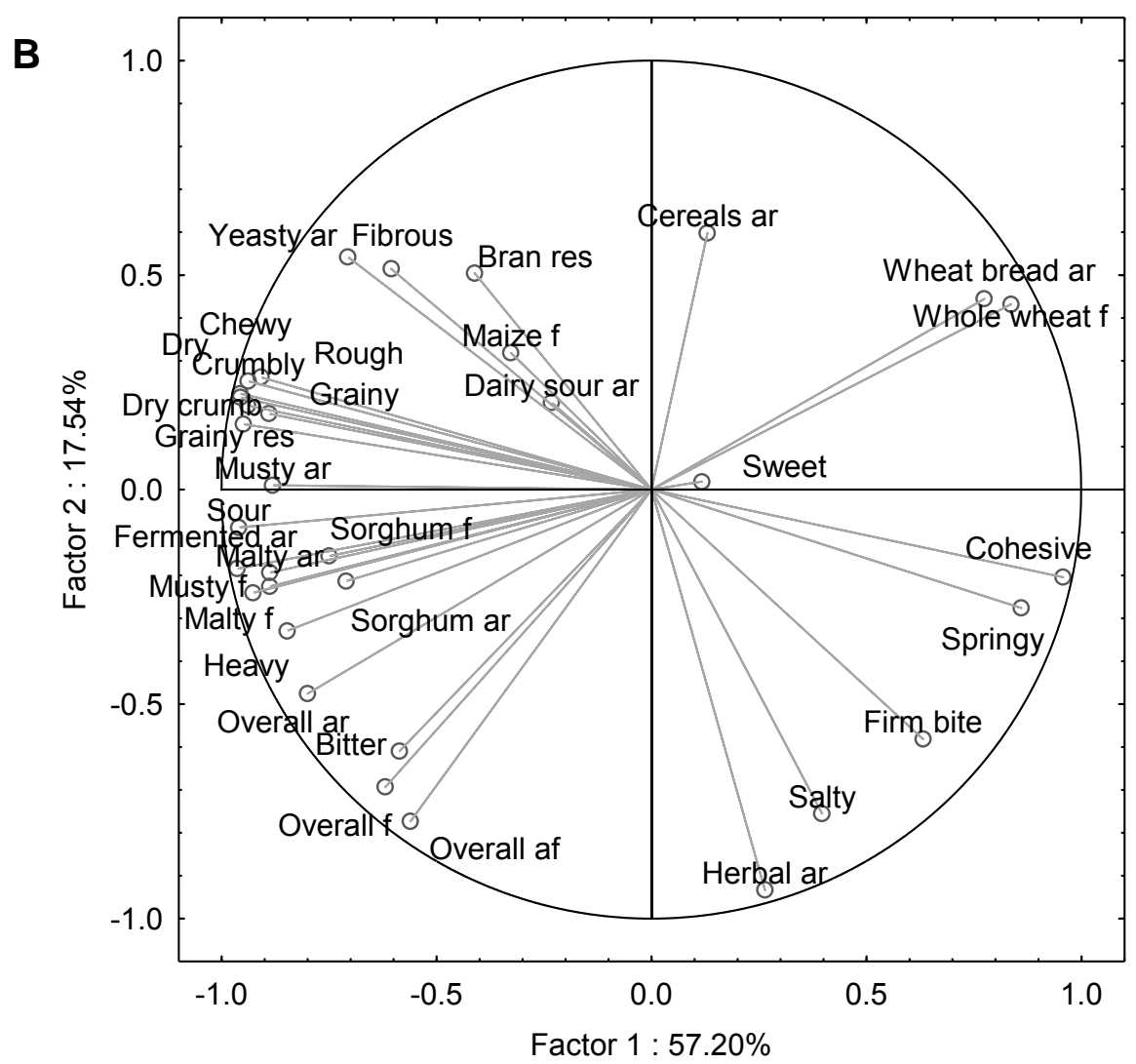

Figure 6 Principal component analysis of sensory properties of eight types of steamed bread samples prepared from three types of cereal flours. A. Plot of the first two principal component scores of bread samples and B. Plot of the first two principal component Loading projections of sensory attributes of breads. Abbreviations: on PC1 and PC2. ar-aroma, f-falvour, af- after taste, res- residue, CWWheatCoarse milled whole wheat, FWWheat- Fine milled whole wheat, ComWheat-Commercial wheat, WRSorg-Whole red sorghum, ComRSorg-Commercial red sorghum, WWhSorg- Whole grain white sorghum, WWhMaize-Whole grain white maize, ComWhMaize- Commercial white maize. 
breads (Table 6). The presence of bran and grainy residues were more evident in non-wheat breads.

PC2 explained an additional $18 \%$ of the variation and separated the rye bread at the bottom from the other breads at the top. Herbal aroma, more salty taste, bitter taste, firmer bite and more intense overall aroma and aftertaste are characteristic attributes of the rye standard bread (Table 6 and Figure 6). This is in contrast to the more intense cereal, yeasty aromas of the breads at the top of the plot. PC3 explained an additional $13 \%$ of the variation and clearly differentiated sorghum breads at the top of the loading plot from maize breads. The aroma of WRSorg and ComRSorg breads did not differ significantly ( $p>0.05)$. As expected the cooked sorghum aroma was perceived more intensely in all sorghum breads (Table 6 and Figure 6). A more intense bitterness, overall flavour and overall aftertaste were noticed in red sorghum breads (Table 6). Cooked maize flavour was more intense in maize breads and cooked whole wheat flavour more clearly associated with the wheat breads. PC3 shows that sorghum breads were more similar to wheat breads than maize breads. Aroma did not differentiate WWhMaize from ComWhMaize breads (Figure 7) and they were associated with cooked maize flavour and intense dairy sour aroma. A sweet taste was noted $(p<0.05)$ in all the breads utilising commercial flours where sugar was added as an ingredient. Although texture varied significantly among the breads, the texture of the three sorghum breads (WRSorg, ComRSorg and WWhSorg) did not differ $(p>0.05)$ (Table 6).

\section{DISCUSSION}

The higher volume of wheat breads is due to the gluten proteins. Gluten forms the framework and is responsible for elasticity and extensibility of wheat dough due to its ability to retain carbon dioxide produced by fermentation ${ }^{27-29}$. The proteins of non-wheat breads are more hydrophobic in nature, insoluble and cannot form a framework that holds air during dough development. As a result non-wheat breads are characterised by low volume ${ }^{30}$. In 


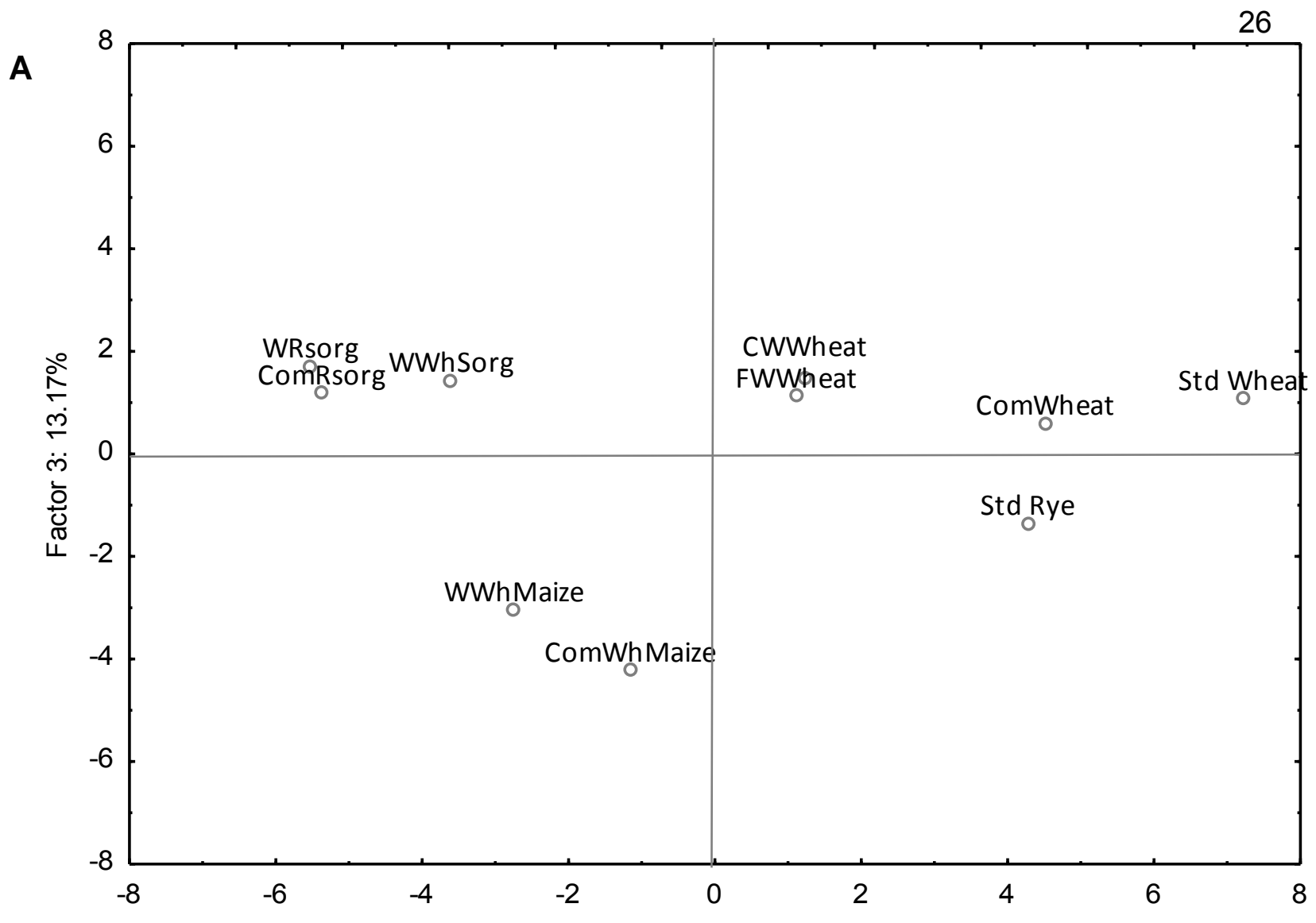

Factor 1: $57.20 \%$

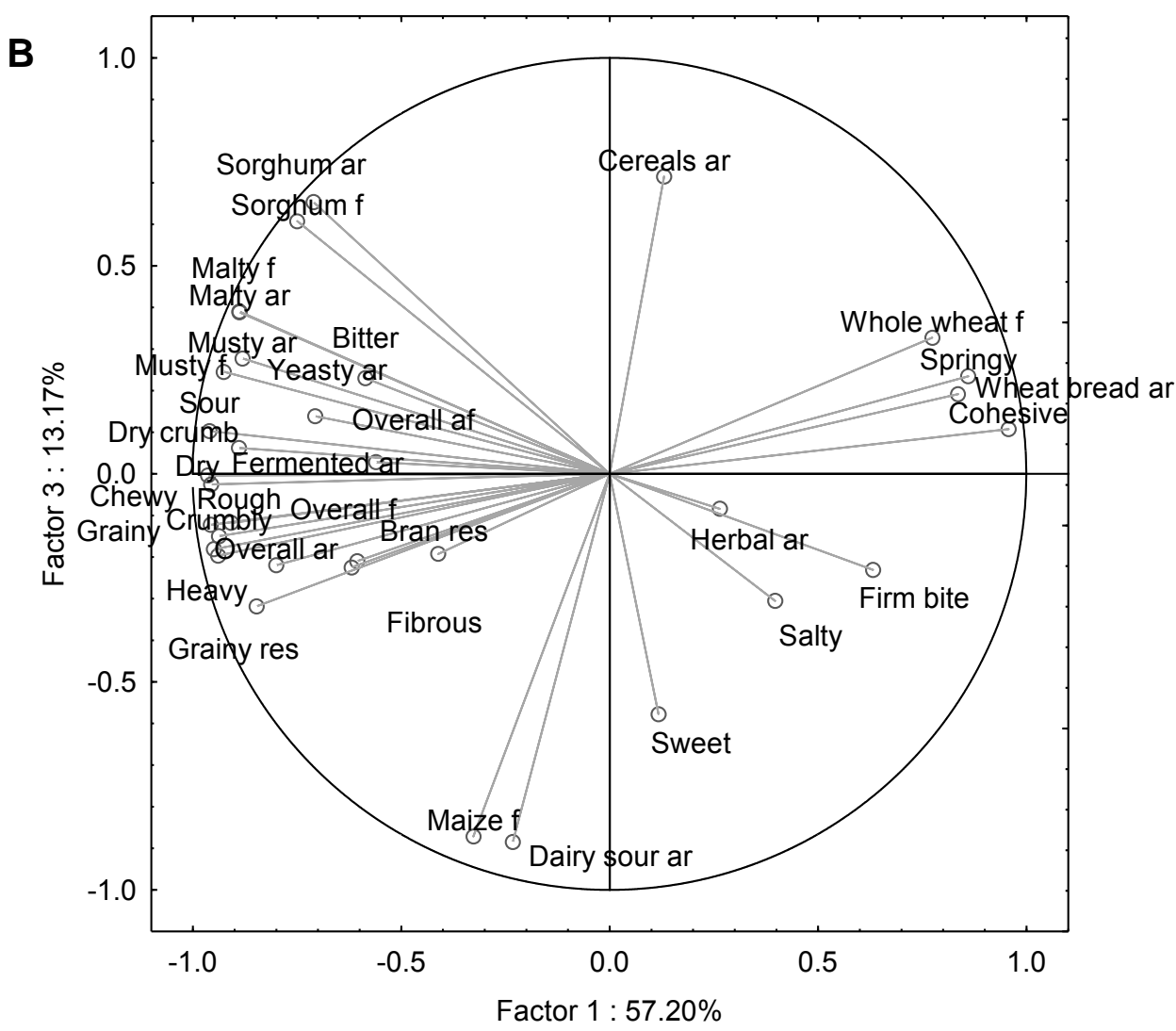

Figure 7 Principal component analysis of sensory properties of eight types of steamed bread samples prepared from three types of cereal flours. A. Plot of the first two principal component scores of bread samples and B. Plot of the first two principal component Loading projections of sensory attributes of breads. Abbreviations: on PC1 and PC3. ar-aroma, f-falvour, af- after taste, res- residue, CWWheatCoarse milled whole wheat, FWWheat- Fine milled whole wheat, ComWheat-Commercial wheat, WRSorg-Whole red sorghum, ComRSorg-Commercial red sorghum, WWhSorg- Whole grain white sorghum, WWhMaize-Whole grain white maize, ComWhMaize- Commercial white maize. 
order to counteract this problem, boiling water was added to pre-gelatinize the starch in maize and sorghum breads thereby forming a thick starch gel to improve texture of nonwheat breads ${ }^{31}$. Taylor, Schober \& Bean $(2006)^{32}$ reported that pre-gelatinized starch results in hydrocolloid-like properties that might hold air bubbles in sorghum bread. Pregelatinization of maize flour reportedly increased the viscoelasticity of dough and caused higher dough consistency, such that the mechanical and handling characteristics of nongluten flour dough improved ${ }^{33}$. Despite the pre-gelatinization process applied in this study, the volume of sorghum and maize breads were low and the crumb crumbly and dry.

The lower volume of CWWheat bread compared to ComWheat bread could be explained by the fact that the larger particles in the whole grain wheat flour interfered with the gluten matrix reducing the ability of gluten to stretch ${ }^{34-36}$. WWhMaize bread had a lower volume than ComWhMaize bread. WWhMaize flour contained larger particles than the ComWhMaize flour. The larger particles might interfere with the starch gel formed and the liquid films around the air cells ${ }^{32}$ causing the lower volume than the bread from maize flour with finer, smaller particles.

Hardness of bread crumb as measured by instrumental analysis increased with decrease in bread volume. Komlenic et al. $(2010)^{36}$ reported the same. The wheat breads showed plastic deformation which is associated with rubbery and soggy (damp, moist) texture ${ }^{37}$. For wheat breads, the coarser the flour the higher the force required to compress the bread crumb. The larger flour particles of coarsely milled flours probably interfered with the gluten network limiting expansion during dough rising causing lower loaf volume and harder crumb. The maize and sorghum breads showed brittle deformation resulting from small strains in a rather solid product that causes the product to break easily ${ }^{37}$. Sanni, Onilude and Fatungase $(1998)^{38}$ reported that maize bread without addition of eggs, crumbled when sliced emphasising the role of structural proteins and lipids. Lipids also assist to incorporate air during dough mixing, lubricate and plasticise the mixture to produce softer crumb texture and 
increase bread volume ${ }^{39}$. Although oil was added to non-wheat breads prepared from commercial flours, the breads were still crumbly, hard, brittle with dry crumb to the same extent as non-wheat breads in which oil was not added.

The dry texture, presence of bran particles and grainy residue of whole maize and sorghum breads could possibly be due to the high proportion of large particles (1000 $\mu \mathrm{m}$ to $1400 \mu \mathrm{m})$ in these flours which also resulted in a chewier crumb. Water absorption of dough is dependent on the particle size of flour and large particles absorb water more slowly than smaller ones ${ }^{40,41}$. When utilizing non-wheat flours with large particles for bread making, Carson et al. (2000) $)^{42}$ also reported more rough and coarse end products. Hugo et al. $(2000)^{43}$ established that sorghum flour for bread making resulted in drier, grittier and firmer crumb. Some of the large flour particles might have been resistant to the gelatinization step applied, causing unevenness in crumb structure and gritty, hard crumbs.

The use of finer ComWhMaize flour also resulted in denser, harder and firmer bread crumb compared to WWhMaize bread with more coarse particles. Smaller flour particles probably absorb more water due to a larger surface area and they probably adhered closer to each other. Schober et al. (2005) $)^{40}$ observed that for non-wheat breads, fine crumb structure is positively related to higher crumb firmness. In sourdough wheat breads the drier the bread crumb the more force was needed to compress the bread crumb ${ }^{41}$. The hardness of bread increased with increased crumb denseness. The denser crumb of non-wheat breads are however a desirable quality in the diet of rural Basotho. Dense breads are heavier and are perceived to satiate for a longer period. It is possible that the frozen storage of the bread before evaluation may have also contributed to the poorer texture of some of the breads due to greater predisposition for retrogradation and staling. The long cooking time of $90 \mathrm{~min}$, as typically practiced by Basotho could also be a contributing factor to the hardness of breads. 
Besides the differences in volume and texture, colour differences in both the skin and crumb of steamed breads were found. The bread colour reflected the colour of the grain used to produce flour. The darker colour of WRSorg bread may be attributed to staining caused by phenolic pigments (anthocyanins) present in the sorghum pericarp ${ }^{17}$. Commercial wheat and maize flour produced lighter coloured breads than whole grain coarse self milled flours. The commercial flours probably contained less pigmented bran particles. Breads from the commercial flours were perceived as less fibrous by the sensory panel suggesting lower levels of bran fibre ${ }^{44}$. The apparent yellowness of maize breads may be due to pigments e.g. carotenoids present in the maize pericarp and endosperm ${ }^{45}$. Appearance is an important factor in the acceptance of bread. The similarity in colour of the CWWheat and WWhSorg bread could be an important factor to consider when encouraging consumers to substitute white sorghum for wheat during bread making.

Non-wheat breads were characterised by more complex flavours dominated by intense fermented aroma, sour taste and dairy sour aroma, malty and musty flavours compared to blander wheat breads. Sourness is a typical characteristic of breads prepared from ground cereals using sourdough ${ }^{46}$. The TTA and $\mathrm{pH}$ of non-wheat fermented bread dough showed higher acidity than wheat breads. Grain flours vary in amounts of fermentable carbohydrates $^{47}$ of which wheat is generally reported to have lower total fermentable sugar $\left(3-4 \mathrm{~g} \mathrm{I}^{-1}\right)$ than maize and sorghum ${ }^{48}$. Apart from the chemical composition of the substrate, the more intense fermented aroma and sour taste were due to the longer fermentation time ${ }^{49}$, applied to non-wheat breads. An intense acidic flavour of sorghum and maize bread were previously reported ${ }^{38,42}$. Sorghum breads and wheat breads were relatively closer in flavour than maize breads which had a distinctly dairy sour aroma and cooked maize flavour.

The standard breads and wheat breads had more intense salt and sweet tastes compared to non-wheat breads. The intense sourness in non-wheat breads probably masked salt and sweet tastes. The differences were also due to the formulations with more salt in wheat 
breads than in non-wheat breads as practiced in Lesotho. The sweeter taste of breads prepared from commercial flours resulted from sugar that was included in the formulations for these products. Although the same amount of sugar was added in ComRSorg and ComWhMaize breads, the sweet taste was more intense in ComWhMaize probably because the bitter taste in red sorghum masked the sweet taste. Sorghum whole grains are a particularly rich source of phenolic compounds (catechin and procyanidin B1) that could cause bitter taste ${ }^{50}$. Red sorghum bread had stronger musty/earthy aroma and malty flavours. Germination encourages the bioactivity of the grain that give rise to new flavours such as malty ${ }^{34}$. The cause of a malty aroma and flavour in sorghum breads needs further investigation.

This study showed the difference between using self-milled whole grain flours and commercial flours on TTA and $\mathrm{pH}$ of sourdough. The self-milled whole flours consisted of the starch endosperm, germ and bran in similar proportions as represented in the original grain. The composition for commercial flours was not known. Whole grain flours tend to increase production of lactic acid in sourdough ${ }^{47}$. The process depends on the microbial flora present in the fermentation matrix together with the buffering ability of the flour used and the ratio of lactic and acetic acid present in the mixture ${ }^{51,52}$. Flour with a higher proportion of bran has higher buffering capacity because of the higher alpha-amylase activity on the outer parts of the grains ${ }^{47}$. Likewise, if the outer parts have been removed the flour tends to have low buffering capacity; therefore commercial flours normally have lower buffering capacity than whole grain flours ${ }^{53}$.

\section{CONCLUSION}

This study provided insight on the sensory properties of steamed bread as prepared in urban and rural Lesotho. The type of cereal and milling properties of the flour used has substantial effects on the physical and sensory properties of the bread. Steamed wheat breads have larger volume, softer crumb and a blander flavour compared to sorghum and maize breads. 
Both sorghum and maize steamed breads prepared according to traditional Basotho procedures are characterised by low loaf volume and denser crumb. The non-wheat breads have more complex and strong flavours and aroma notably sourness, musty, malty, dairy sour and fermented aroma. The texture of the non-wheat bread types is heavy, chewy, dry, fibrous and more brittle. More research is needed to optimise the sensory properties of the non-wheat steamed breads. Possibilities include: controlling flour particle size for bread making purposes, altering formulation e.g. compositing non-wheat flours with wheat, addition of protein sources and gums, altering the amount of water use, improving on the pre-gelatinization process and optimising steam cooking conditions. These improvements are needed to increase acceptance of sorghum and maize breads among the younger generation and modernised Basotho.

\section{Acknowledgements}

The Culinary Equipment Company -Lanseria, South Africa for use of mill and facilities.

This work is based upon research supported by the National Research Foundation of South Africa (NRF). Any opinion, findings and conclusions or recommendations expressed in this material are those of the authors and therefore NRF do not accept any liability in thereto. 


\section{References}

1. Ashton EH, A sociological sketch of Sotho diet. Transactions of the Royal Society of South Africa:147-214 (1939).

2. Food and Agriculture Organisation and World Food Programme, Crop and food supply assessment mission to Lesotho.

http://www.fanrpan.org/documents/d00317/FAO_WFP_Lesotho_report_Jun 2007.pdf [20 October 2009.

3. Lesotho Ministry of Agriculture and Food Security, Agricultural Situation Report 2005/062006-07, Maseru Lesotho (2008).

4. Huang S, Quail K, Moss R and Best J, Objective methods for the quality assessment of Northern-style Chinese steamed bread. Journal of Cereal Science 21:49-55 (1995).

5. Huang S, Yun S, Quail K and Moss R, Establishment of flour quality, guidelines for northern style Chinese steamed bread. Journal of Cereal Science 24:179-185 (1996).

6. Huang S, Wheat products: 2. Breads, Cakes, Cookies, Pastries, and Dumplings, in Asian Foods Science \& Technology, ed. by Ang C, Liu K and Huang Y-W. Technomic, Holland, pp 71-109 (1999).

7. Sun M, Compare the steamed bread made from starter with the one from yeast. Hot Spot and Research 25:18-19 (2007).

8. Wu C, Liu R, Huang W, Rayas-Duarte P, Wang F and Yao Y, Effect of sourdough fermentation on the quality of Chinese Northern-style steamed breads. Journal of Cereal Science 56:127-133 (2012).

9. Coetzee R, Funa food from Africa-Roots of traditional African food culture. Butterworths, Durban (1982).

10. Manley M and Nel M, Investigation of the suitability of Western and Southern Cape wheat flour for production of traditional South African steamed bread. S Afr J Plant \& Soil 16:135-142 (1999).

11. Lombard G, Weinert I, Minnaar A and Taylor J, Preservation of South African steamed bread using hurdle technology. Lebensmittel-Wissenschaft Und-Technologie-Food Science and Technology 33:138-143 (2000).

12. Nche P, Odamtten G, Nout $M$ and Rombouts F, Soaking of maize determines the quality of aflata for kenkey production. Journal of Cereal Science 24:291-297 (1996).

13. Nout M, Kok B, Vela E, Nche P and Rombouts F, Acceleration of the fermentation of kenkey, an indigenous fermented maize food of Ghana. Food Research International 28:599-604 (1995).

14. Cayot N, Sensory quality of traditional foods. Food Chemistry 101:154-162 (2007).

15. Stone $\mathrm{H}$ and Sidel J, Sensory Evaluation Practices. Elsevier Academic Press, Amsterdam (2004).

16. Taylor J, Methods to be used to identify and specify characteristics desired by industrial processors that use sorghum as an input. Technical Report \#2, USAID, Gaborone Botswana (2001).

17. Kebakile MM, Rooney LW, de Kock HL and Taylor JRN, Effects of sorghum type and milling process on the sensory characteristics of sorghum porridge. Cereal Chemistry 85:307-313 (2008).

18. International AACC, Approved Methods of the American Association of Cereal Chemists Methods 08-01, 30-25, 44-15A, 46-30, AACC International Press, St Paul MN USA (2000).

19. FAO, Food Energy. Methods of Analysis and Conversion Factors. FAO Food Nutrition Paper 77, Food and Agriculture Organization, Rome, pp 18-37 (2003).

20. Loenner C, Welander T, Molin N, Dostalek M and Blickstad E, The microflora in a sour dough started spontaneously on typical Swedish rye meal. Food Microbiology 3:3-12 (1986).

21. Henshaw $E$ and Ikpoh I, Effect of single bacterial starter culture on dough reduction during controlled fermentation of cassava tubers for foofoo production. Malaysian J of Microbiol 6:57-61 (2010).

22. Campbell A, Penfield M and Griswold R, The experimental study of food. Constable, London England (1980). 
23. AACC International Approved methods of analysis, Measurement of bread firmness by universal testing machine 740901, AACC International Press, St Paul MN USA (2009).

24. Einstein $M$, Descriptive techniques and their hybridization, in Sensory Science Theory and Applications in Foods, ed. by Lawless $\mathrm{H}$ and Klein B. Marcel Dekker, New York USA, pp 317-338 (1991).

25. Kundi S, Starch digestibility of porridges from unrefined and refined maize, pearl millet and sorghum. University of Pretoria (2002).

26. Phattanakulkaewmorie N, Paseephol T and Moongngarm A, Chemical compositions and physico-chemical properties of malted sorghum flour and characteristics of gluten free bread. (2011).

27. Hamelman J, Bread. A baker's book of techniques and recipes. John Wiley \& Sons, USA (2004).

28. Sluimer P, Principles of bread making. Functionality of raw materials and process steps. AACC International Press, St Paul MN USA (2005).

29. Mondal A and Datta A, Bread baking - A review. Journal of Food Engineering 86:465-474 (2008).

30. Duodu K and Taylor J, Quality of breads made with non-wheat flours, in Breadmaking: Improving Quality, ed. by Cauvain S. Woodhead, Boca Raton USA, pp 754-782 (2012).

31. Satin M, Bread without wheat. New Scientist 118:56-59 (1988).

32. Taylor J, Schober T and Bean S, Novel food and non-food uses for sorghum and millets. Journal of Cereal Science 44:252-271 (2006).

33. Brites C, Trigo M, Santos C, Collar C and Rosell C, Maize-Based Gluten-Free Bread: Influence of Processing Parameters on Sensory and Instrumental Quality. Food and Bioprocess Technology 3:707-715 (2010).

34. Heinio R, Sensory attributes of bakery products, in Bakery products: Science and Technology, ed. by Hui Y. Wiley-Blackwell, Hoboken USA, pp 285-298 (2006).

35. Stojceska $V$, Dietary fibre from brewer's spent grain as a functional ingredient in bread making technology, in Flour and Breads and their Fortification in Health and Disease Prevention, ed. by Preedy V, Watson R and Patel V. Elsevier, Amsterdam, pp 171-179 (2011).

36. Komlenic D, Ugarcic-Hardi Z, Jukic M, Planinic M, Bucic-Kojic A and Strelec I, Wheat dough rheology and bread quality effected by Lactobacillus brevis preferment, dry sourdough and lactic acid addition. International Journal of Food Science and Technology 45:1417-1425 (2010).

37. Jeromidis $G$, Mechanical and fracture properties of cellular and fibrous materials, in Feeding and the Texture of Food, ed. by Vincent J and Lillford P. Cambridge University Press, USA, pp 1-18 (1991).

38. Sanni A, Onilude A and Fatungase $M$, Production of sour maize bread using starter-cultures. World Journal of Microbiology \& Biotechnology 14:101-106 (1998).

39. Pareyt B, Finnie S, Putseys J and Delcour J, Lipids in bread making: Sources, interactions, and impact on bread quality. Journal of Cereal Science 54:266-279 (2011).

40. Schober T, Messerschmidt M, Bean S, Park S and Arendt E, Gluten-free bread from sorghum: Quality differences among hybrids. Cereal Chemistry 82:394-404 (2005).

41. Katina K, High fibre baking, in Bread Making Improving Quality, ed. by Cauvain S. Woodhead, London England, pp 487-497 (2003).

42. Carson L, Setser $C$ and Sun X, Sensory characteristics of sorghum composite bread. International Journal of Food Science and Technology 35:465-471 (2000).

43. Hugo L, Rooney L and Taylor J, Malted sorghum as a functional ingredient in composite bread. Cereal Chemistry 77:428-432 (2000).

44. Oladunmoye O, Akinoso R and Olapade A, Evaluation of some physical-chemical properties of wheat, cassava, maize and cowpea flours for bread making. Journal of Food Quality 33:693-708 (2010). 
45. De la Hera E, Talegon M, Caballero $\mathrm{P}$ and Gomez $\mathrm{M}$, Influence of maize flour particle size on gluten-free breadmaking. Journal of the Science of Food and Agriculture 93:924-932 (2013).

46. Hammes W and Gänzle M, Sourdough breads and related products. Microbiology of Fermented Foods 1:199-216 (1998).

47. Katina K, Sourdough: a tool for the improved flavour, texture and shelf-life of wheat bread. VTT University of Helsinki, Helsinki Finland (2005).

48. Salim-ur-Rehman, Paterson A and Piggott J, Flavour in sourdough breads: a review. Trends in Food Science \& Technology 17:557-566 (2006).

49. Charalampopoulos D, Wang R, Pandiella S and Webb C, Application of cereals and cereal components in functional foods: a review. International Journal of Food Microbiology 79:131-141 (2002).

50. Kebakile $\mathrm{M}$, Rooney L, de Kock $\mathrm{H}$ and Taylor J, Effects of sorghum type and milling process on the sensory characteristics of sorghum porridge. Cereal Chemistry 85:307-313 (2008).

51. Hansen A and Hansen B, Flavour of sourdough wheat bread crumb. Zeitschrift Fur Lebensmittel-Untersuchung Und-Forschung 202:244-249 (1996).

52. Jekle $M$, Houben $A$, Mitzscherling $M$ and Becker $T$, Effects of selected lactic acid bacteria on the characteristics of amaranth sourdough. Journal of the Science of Food and Agriculture 90:23262332 (2010).

53. Sahlin P, Fermentation as a method of food processing production of organic acids, $\mathrm{pH}$ development and microbial growth in fermenting cereals, in Department of Applied Nutrition and Food Chemisty, Lund Institute of Technology Lund University (1999). 